\title{
Characterisation of stable isotopes to identify residence times and runoff components in two meso-scale catchments in the Abay/Upper Blue Nile basin, Ethiopia
}

\author{
S. Tekleab ${ }^{1,2,3,4}$, J. Wenninger ${ }^{1,4}$, and S. Uhlenbrook ${ }^{1,4}$ \\ ${ }^{1}$ UNESCO-IHE Institute for Water Education, Department of Water Science and Engineering, P.O. Box 3015, \\ 2601 DA Delft, the Netherlands \\ ${ }^{2}$ Addis Ababa University, Institute for Environment, Water and Development, P.O. Box 1176, Addis Ababa, Ethiopia \\ ${ }^{3}$ Hawassa University, Institute of Technology, Department of Irrigation and Water Resources Engineering, P.O. Box 5, \\ Hawassa, Ethiopia \\ ${ }^{4}$ Delft University of Technology, Faculty of Civil Engineering and Applied Geosciences, Water Resources Section, \\ P.O. Box 5048, 2600 GA Delft, the Netherlands
}

Correspondence to: S. Tekleab (siraktekleab@yahoo.com)

Received: 31 July 2013 - Published in Hydrol. Earth Syst. Sci. Discuss.: 13 August 2013

Revised: 20 May 2014 - Accepted: 24 May 2014 - Published: 26 June 2014

\begin{abstract}
Measurements of the stable isotopes oxygen-18 $\left({ }^{18} \mathrm{O}\right)$ and deuterium $\left({ }^{2} \mathrm{H}\right)$ were carried out in two meso-scale catchments, Chemoga $\left(358 \mathrm{~km}^{2}\right)$ and Jedeb $\left(296 \mathrm{~km}^{2}\right)$ south of Lake Tana, Abay/Upper Blue Nile basin, Ethiopia. The region is of paramount importance for the water resources in the Nile basin, as more than $70 \%$ of total Nile water flow originates from the Ethiopian highlands. Stable isotope compositions in precipitation, spring water and streamflow were analysed (i) to characterise the spatial and temporal variations of water fluxes; (ii) to estimate the mean residence time of water using a sine wave regression approach; and (iii) to identify runoff components using classical two-component hydrograph separations on a seasonal timescale.

The results show that the isotopic composition of precipitation exhibits marked seasonal variations, which suggests different sources of moisture generation for the rainfall in the study area. The Atlantic-Indian Ocean, Congo basin, Upper White Nile and the Sudd swamps are the potential moisture source areas during the main rainy (summer) season, while the Indian-Arabian and Mediterranean Sea moisture source areas during little rain (spring) and dry (winter) seasons. The spatial variation in the isotopic composition is influenced by the amount effect as depicted by moderate coefficients of determination on a monthly timescale ( $R^{2}$ varies from 0.38 to $0.68)$ and weak regression coefficients $\left(R^{2}\right.$ varies from 0.18
\end{abstract}

to 0.58) for the altitude and temperature effects. A mean altitude effect accounting for $-0.12 \% / 100 \mathrm{~m}$ for ${ }^{18} \mathrm{O}$ and $-0.58 \% / 100 \mathrm{~m}$ for ${ }^{2} \mathrm{H}$ was discernible in precipitation isotope composition.

Results from the hydrograph separation on a seasonal timescale indicate the dominance of event water, with an average of 71 and $64 \%$ of the total runoff during the wet season in the Chemoga and Jedeb catchments, respectively.

Moreover, the stable isotope compositions of streamflow samples were damped compared to the input function of precipitation for both catchments. This damping was used to estimate mean residence times of stream water of 4.1 and 6.0 months at the Chemoga and Jedeb catchment outlets, respectively. Short mean residence times and high fractions of event water components recommend catchment management measures aiming at reduction of overland flow/soil erosion and increasing of soil water retention and recharge to enable sustainable development in these agriculturally dominated catchments. 


\section{Introduction}

Environmental isotopes as tracers are commonly applied for examination of runoff generation mechanisms on different spatial and temporal scales (e.g. Uhlenbrook et al., 2002; Laudon et al., 2007; Didszun and Uhlenbrook, 2008). Isotope tracer studies are used for hydrograph separations (Sklash and Farvolden, 1979; Buttle, 1994), provide additional information for identifying source areas and flow pathways under different flow conditions, and estimate the mean residence time of a catchment (Soulsby et al., 2000; Uhlenbrook et al., 2002; McGuire et al., 2005; McGuire and McDonnell, 2006; Soulsby and Tetzlaff, 2008). The application of isotopes in catchment hydrology studies has been carried out in small experimental catchments to meso-scale catchments (e.g. McDonnell et al., 1991; Uhlenbrook et al., 2002; Tetzlaff et al., 2007a) and large-scale catchments (Taylor et al., 1989; Liu et al., 2008).

Only few studies have been undertaken to characterise water cycle components using stable isotopes in Ethiopia (e.g. Rozanski et al., 1996; Kebede, 2004; Levin et al., 2009; Kebede and Travi, 2012). The results from these studies indicate that stable isotope composition of precipitation is only little affected by the typical dominant controls: amount, altitude and continental effects. Despite low mean annual temperature and high altitude, the Ethiopian meteoric water (e.g. the Addis Ababa station of the International Atomic Energy Agency (IAEA)) exhibits less negative isotopic composition as compared to the East African meteoric water (e.g. Nairobi, and Dar es Salaam) (Levin et al., 2009; Kebede and Travi, 2012). The literature suggests different reasons for the less negative isotopic composition of the Addis Ababa station in Ethiopia. For instance, Joseph et al. (1992) indicated that the moisture from the Indian Ocean that results in an initial stage of condensation vapour, which did not undergo a major rainout fractionation effect, is likely the main reason for higher isotopic composition. Levin et al. (2009) hypothesised that the less negative isotopic composition in Addis Ababa is due to advection of recycled moisture from the Congo basin and the Sudd wetland. Rozanski et al. (1996) and Darling and Gizaw (2002) show that the increased sea surface temperature at the moisture source, and evaporation condition at the sources, are attributed to the less negative isotopic composition for the Ethiopian meteoric water as compared to the East African meteoric water.

Despite the paramount importance of water resources in the Abay/Upper Blue Nile area for the whole Nile basin, the usefulness of stable isotope data for catchment hydrological studies is largely unexplored. Very little is known about the use of stable isotopes for hydrological studies in the region. However, stable isotopes have the potential to provide enormous benefit with respect to hydrological process understanding and sustainable planning of water resource management strategies and policies in such data-scarcs areas (Hrachowitz et al., 2011a). This potential has been demonstrated in numerous other regions worldwide (Kendall and Caldwell, 1998; Kendall and Coplen, 2001; Gibson et al., 2005; Barthold et al., 2010; Kirchner et al., 2010).

The use of isotope tracer techniques to understand mean residence times (MRTs) and residence time distributions (RTDs) has received a lot of attention (Rodgers et al., 2005a; McGuire and McDonnell, 2006). They are used to gain a better understanding of flow path heterogeneities (Dunn et al., 2007), to get insights into the internal processes of hydrological systems, and are used as a tool for hydrological model construction and evaluation (Uhlenbrook and Leibundgut, 2002; Wissmeier and Uhlenbrook, 2007; Hrachowitz et al., 2011b). Furthermore, they can be used as fundamental catchment descriptors, providing information about the storage, flow pathways and sources of water (McGuire and McDonnell, 2006), and are used for conceptualising the differences in hydrological processes by comparing different catchments (McGuire et al., 2005; Soulsby et al., 2006; Tetzlaff et al., 2009). The steady state assumption of fluxes for estimating the mean residence time has been commonly used, although time-invariant mean residence times do not exist naturally in real-world catchments. To circumvent this issue, a few recent studies developed a method for estimating time-variable mean residence times (e.g. van der Velde et al., 2010; Botter et al., 2011; Heidbüchel et al., 2012; Hrachowitz et al., 2013).

In the present study, the investigation of meteoric water in the source of the Abay/Upper Blue Nile basin is undertaken as the basis for characterisation and better understanding of the dominant runoff components. This is used as a baseline study for future hydrological studies using environmental isotopes in the region. The main objectives of this study are (a) to characterise the spatio-temporal variations in the isotopic composition in precipitation, spring and stream water; (b) to estimate the mean residence time of stream water; and (c) to separate the hydrograph on a seasonal timescale in the two adjacent meso-scale catchments, Chemoga and Jedeb in the Abay/Upper Blue Nile basin.

\section{Study area}

The Chemoga and Jedeb rivers are tributaries of the Abay/Upper Blue Nile, located south of Lake Tana, and extend between approximately $10^{\circ} 10^{\prime}$ and $10^{\circ} 40^{\prime} \mathrm{N}$ latitude and $37^{\circ} 30^{\prime}$ and $37^{\circ} 54^{\prime} \mathrm{E}$ longitude. Both rivers originate from the Choke Mountains at an elevation of $4000 \mathrm{~m}$ a.s.l. (see Fig. 1). The climate in these catchments has a distinct seasonality with three seasons: (i) summer as the main rainy season from June to September, (ii) winter as the dry season from October to February, and (iii) spring as the short rainy season from March to May (NMSA, 1996).

The long-term average annual temperature over the period of 1973-2008 at Debre Markos weather station is about $16.3^{\circ} \mathrm{C}$. The mean precipitation ranges between 1342 and 


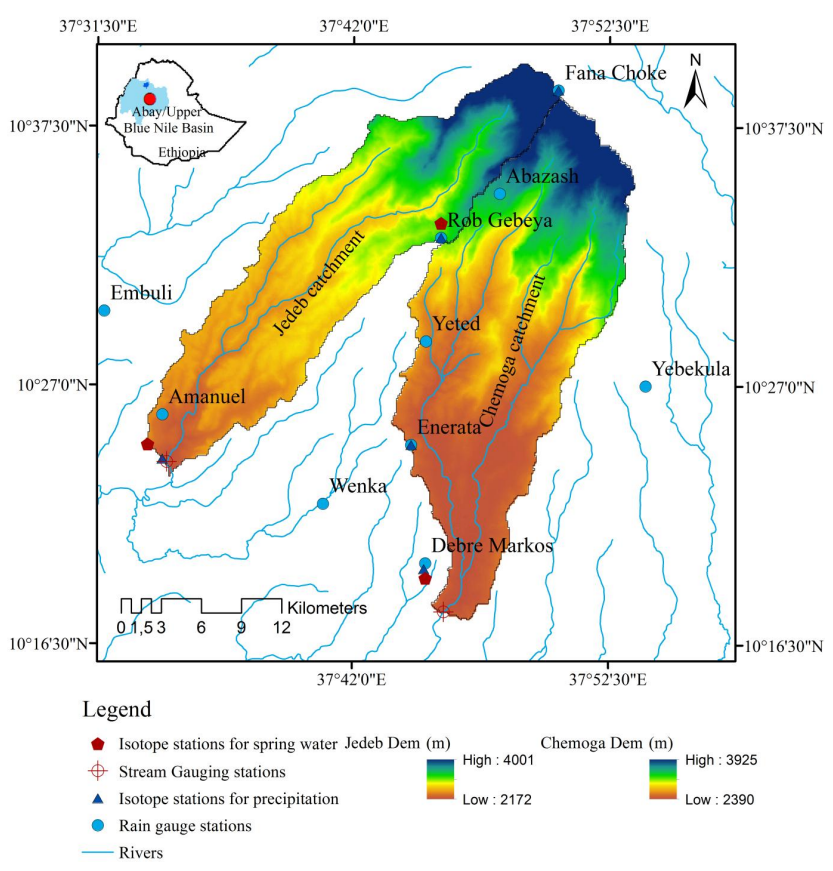

Figure 1. Location of the study area indicating the network of rain gauges, streamflow gauges and sampling points for stable isotopes of precipitation, surface water and spring water. The red dot within the Ethiopian map (inset, top left) indicates the location of the Chemoga and Jedeb catchments.

$1434 \mathrm{~mm} \mathrm{a}^{-1}$ (1973-2010) in the lower and upper parts of the catchments.

In these two catchments subsistence farming is commonly practiced. The farmers rely on rain-fed agriculture for their livelihoods. Barley, oats and potato are the main crops grown in the upland area, whereas wheat, tef and maize are grown in the middle and lower parts of the catchments. According to the studies by Bewket and Sterk (2005) and Teferi et al. $(2010,2013)$, the land use in the Chemoga catchment had been subjected to changes before the 1950s. The major change was the increase in cultivated area at the expense of open grazing area and a slight increase in plantation forest cover due to eucalyptus plantations. Natural vegetation cover can hardly be found in both catchments. A recent study by Teferi et al. (2013) showed that $46 \%$ of the Jedeb catchment experienced transitions from one land cover to another over the last 52 years. Nowadays, about $70 \%$ of the land is used for agriculture and $3 \%$ is forest plantations, and the remaining percentages are utilised for other land uses (pasture land, bare land with shrubs and bushes).

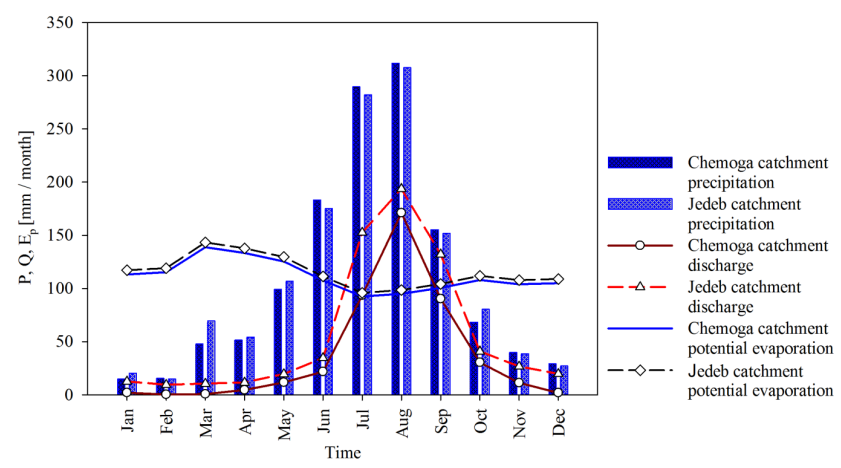

Figure 2. Intra-annual variability of hydro-climate data for the period 2008-2010 showing similar climate and distinct streamflow response in the Chemoga and Jedeb catchments. $P, Q$ and $E_{\mathrm{p}}$ on the $y$ axis stand for precipitation, discharge and potential evaporation, respectively.

\section{Methodology}

\subsection{Hydro-meteorological data collection}

Streamflow data sets are based on manual water level measurements (daily at 6 a.m. and 6 p.m.) at Chemoga and Jedeb gauging stations from 1 July 2009 to 31 October 2011. Based on the stage discharge relationships rating curves were developed using regression models. A network of ten manual rain gauges was established in July 2009. Consequently, daily precipitation data were collected from these stations over the same period as the stream flows. Similarly, the mean daily minimum and maximum temperature data at Debre Markos station were obtained from the Ethiopian National Meteorological Agency. Regionalisation of the temperature data at Debre Markos station was used to estimate the temperature at Enerata, Rob Gebeya, Fana Choke, and Yewla stations based on a decrease of $0.6^{\circ} \mathrm{C}$ in temperature per $100 \mathrm{~m}$ increase in altitude. The catchment average precipitation amount, catchment mean annual temperature, potential evaporation, and isotopic composition of precipitation were computed using the Thiessen polygon method. Due to the limited climatic data availability, the potential evaporation was computed using the Hargreaves method (Hargreaves and Samani, 1982). The method was selected due to the fact that other meteorological data (e.g. humidity, solar radiation, wind speed, etc.) were missing and only temperature data were available for the study catchments. The intra-annual variability of hydroclimatic data within the catchments is shown in Fig. 2. Furthermore, detailed descriptions of the hydro-meteorological data and isotope sampling sites are presented in Tables 1 and 2 , respectively.

\subsection{Field measurements and sampling}

To characterise the spatial and temporal variability of stable isotope composition in precipitation, spring discharge and 
Table 1. Descriptions of hydro-meteorological characteristics of investigated catchments (2008-2010). $P, Q, E_{\mathrm{p}}$, and $E$ stand for catchment average precipitation, runoff, potential evaporation and actual evaporation, respectively.

\begin{tabular}{lrrrrrrr}
\hline & & & & & & $\begin{array}{r}\text { Mean annual } \\
\text { Catchment }\end{array}$ \\
& Area $\left(\mathrm{km}^{2}\right)$ & \multicolumn{4}{c}{$\begin{array}{c}\text { Mean annual values }\left(\mathrm{mm} \mathrm{a}^{-1}\right) \\
\text { temperature }\left({ }^{\circ} \mathrm{C}\right)\end{array}$} \\
\cline { 3 - 8 } & & $P$ & $Q$ & $E_{\mathrm{p}}$ & $E$ & $T$ \\
\hline Chemoga & 358 & 1303 & 588 & 1338 & 715 & 13.9 \\
Jedeb & 296 & 1306 & 692 & 1384 & 614 & 15 \\
\hline
\end{tabular}

Table 2. Description of isotope sample locations and total number of samples taken during the investigation period (August 2008August 2011).

\begin{tabular}{lllrrl}
\hline Sample type & Location name & Abbreviation & $\begin{array}{r}\text { Elevation } \\
\text { (m a.s.l.) }\end{array}$ & $\begin{array}{r}\text { Number of } \\
\text { samples }\end{array}$ & Investigation period \\
\hline Precipitation & Debre Markos & P-DM & 2515 & 58 & Aug 2008-Aug 2011 \\
Precipitation & Enerata & P-EN & 2517 & 24 & Jul 2009-Aug 2011 \\
Precipitation & Rob Gebeya & P-RG & 2962 & 53 & Oct 2008-Aug 2011 \\
Precipitation & Fana Choke & P-FC & 3993 & 41 & Jul 2009-Aug 2011 \\
Precipitation & Yewla & P-YW & 2219 & 46 & Jul 2009-Aug 2011 \\
Spring & Debre Markos & S-DM & 2339 & 64 & Aug 2008-Aug 2011 \\
Spring & Rob Gebeya & S-RG & 2820 & 53 & Oct 2008-Aug 2011 \\
Spring & Yewla & S-YW & 2255 & 59 & Jul 2009-Aug 2011 \\
Stream & Chemoga & Q-CH & 2402 & 83 & Jul 2009-Jul 2011 \\
Stream & Jedeb & Q-JD & 2190 & 98 & Jul 2009-Jul 2011 \\
\hline
\end{tabular}

streamflow, field investigations were undertaken from August 2008 until August 2011. At five different locations, plastic funnels were used to collect the precipitation samples for the analysis of isotopic signature in precipitation. The samples were collected on a bi-weekly basis.

The rainfall sample collectors have a capacity of 10 litres fitted with a vertical funnel with a mesh on top to avoid dirt and a long plastic tube to minimise evaporation out of the collection device according to the IAEA (2009) technical procedure for sampling. Spring water was sampled at three locations at different altitudes on a weekly basis, and the two weekly samples were mixed and taken for the analysis. Streamflow was sampled at the outlet of the Chemoga and Jedeb rivers on a weekly basis. During sampling, the water was filled into $2 \mathrm{~mL}$ glass bottles and closed immediately to avoid fractionation due to evaporation. Details about isotope sample locations and investigation periods are given in Table 2 .

\subsection{Laboratory analysis}

All water samples were analysed at UNESCO-IHE (Delft, the Netherlands) using an LGR liquid-water isotope analyser. The stable isotopic composition of oxygen-18 and deuterium are reported using the $\delta$ notation, defined according to the Vienna Standard Mean Ocean Water (VSMOW) with $\delta^{18} \mathrm{O}$ and $\delta^{2} \mathrm{H}$. The accuracy of the LGR liquid-water isotope analyser measurements was $0.2 \%$ for $\delta^{18} \mathrm{O}$ and $0.6 \%$ for $\delta^{2} \mathrm{H}$, respectively.

\subsection{Hydrograph separation on a seasonal timescale}

The classical steady state mass balance equations of water and tracer fluxes in a catchment were used in this study to separate the hydrograph into different components. The assumptions used for the hydrograph separations and the basic concepts are described in detail by e.g. Sklash and Farvolden (1979), Wels et al. (1991) and Buttle (1994).

The mass balance equation used for a time-based twocomponent separation using $\left({ }^{18} \mathrm{O}\right)$ as a tracer can be described as

$$
\begin{aligned}
& Q_{\mathrm{T}}=Q_{\mathrm{E}}+Q_{\mathrm{Pe}} \\
& C_{\mathrm{T}} Q_{\mathrm{T}}=C_{\mathrm{E}} Q_{\mathrm{E}}+C_{\mathrm{Pe}} Q_{\mathrm{Pe}},
\end{aligned}
$$

where $Q_{\mathrm{T}}$ is the total runoff $\left[\mathrm{m}^{3} \mathrm{~s}^{-1}\right]$, and $Q_{\mathrm{E}}\left[\mathrm{m}^{3} \mathrm{~s}^{-1}\right]$ and $Q_{\mathrm{Pe}}\left[\mathrm{m}^{3} \mathrm{~s}^{-1}\right]$ are the runoff event and pre-event components, respectively. $C_{\mathrm{T}}$ is the total concentration of tracer observed in total runoff [\%oVSMOW], and $C_{\mathrm{E}}[\% \circ \mathrm{VSMOW}]$ and $C_{\mathrm{Pe}}$ [\%oVSMOW] are the tracer concentrations in event and preevent water, respectively. Combining Eqs. (1) and (2), the contribution of event water and pre-event water to the total runoff can be estimated as 


$$
\begin{aligned}
& Q_{\mathrm{E}}=Q_{\mathrm{T}}\left(\frac{C_{\mathrm{T}}-C_{\mathrm{Pe}}}{C_{\mathrm{E}}-C_{\mathrm{Pe}}}\right) \\
& Q_{\mathrm{Pe}}=Q_{\mathrm{T}}\left(\frac{C_{\mathrm{T}}-C_{\mathrm{E}}}{C_{\mathrm{Pe}}-C_{\mathrm{E}}}\right) .
\end{aligned}
$$

The precipitation isotopic composition was weighted based on the cumulative incremental weighting approach as outlined by McDonnell et al. (1990):

$$
\delta^{18} \mathrm{O}=\frac{\sum_{i=1}^{n} p_{i} \delta_{i}}{\sum_{i=1}^{n} p_{i}},
$$

where $p_{i}$ and $\delta_{i}$ denote the rainfall amount and $\delta$ value, respectively.

Similarly, the monthly discharge isotopic composition in the rivers was weighted using Eq. (6).

$$
\delta^{18} \mathrm{O}=\frac{\sum_{i=1}^{n} Q_{i} \delta_{i}}{\sum_{i=1}^{n} Q_{i}},
$$

where $Q_{i}\left[\mathrm{~m}^{3} \mathrm{~s}^{-1}\right]$ is the daily volumetric flow rate and $\delta_{i}$ $[\% o]$ is the isotopic composition of the streamflow.

Due to the distinct seasonality, the precipitation during the dry (winter) and little rain (spring) seasons does not contribute significantly to the total streamflow, neither as surface nor as subsurface flow. This is due to the fact that the precipitation in these seasons mostly evaporates without producing direct runoff or recharging the groundwater (Kebede and Travi, 2012). To account for the effects of seasonality on the results of hydrograph separation, the end member signature is not taken as a constant value throughout the whole seasons. Consequently, the pre-event water isotopic composition was taken as the monthly isotopic values at each month during the dry (winter) and spring seasons. At the same time, to see the effects of different pre-event end member concentrations on the results of the wet season hydrograph separation, three different end members were estimated: first, the average values for the whole dry season isotope concentration were taken as all end members, second, the average value of the isotopic concentration in the month of February, which represents the baseflow in the rivers, was considered as an end member, and third, the average isotopic concentration of combined dry and spring season concentrations.

The event water $\delta^{18} \mathrm{O}$ end member was taken as the weighted mean isotopic composition of precipitation, in each month for the investigated period. The differences in isotopic composition for event water vary from -6.37 to $-4.24 \%$, and pre-event water from -0.25 to $0.62 \%$ is adequate for the hydrograph separation in these catchments based on the assumptions of classical hydrograph separation described in Buttle (1994).

Hydrograph separation using isotope technique is prone to error due to the uncertainty in the estimation of end member concentrations (e.g. Genereux, 1994; Uhlenbrook and Hoeg, 2003). In this study the uncertainty in the two-component separations during the wet season June to September is evaluated based on the Gaussian error propagation technique according to Eq. (7) (e.g. Genereux, 1994).

$W_{y}=\sqrt{\left(\frac{\partial y}{\partial x 1} W_{x 1}\right)^{2}+\left(\frac{\partial y}{\partial x 2} W_{x 2}\right)^{2}+\ldots+\left(\frac{\partial y}{\partial x n} W_{x n}\right)^{2}}$,

where $W$ represents the uncertainty in the variables indicated in the subscript, assuming that $y$ is a function of the variables $x_{1}, x_{2}, \ldots, x_{n}$ and the uncertainty in each variable is independent of the uncertainty in the others (Genereux, 1994). The uncertainty in $y$ is related to the uncertainty in each of the subscript variables by using Eq. (7). Application of Eq. (7) into Eq. (4) gives the propagated total uncertainty related to the different component computed using Eq. (8).

$$
\begin{aligned}
W & =\left\{\left[\frac{\left(C_{\mathrm{E}}-C_{\mathrm{T}}\right)}{\left(C_{\mathrm{E}}-C_{\mathrm{Pe}}\right)^{2}} \times W_{C_{\mathrm{Pe}}}\right]^{2}+\left[\frac{\left(C_{\mathrm{T}}-C_{\mathrm{Pe}}\right)}{\left(C_{\mathrm{E}}-C_{\mathrm{Pe}}\right)^{2}} \times W_{\mathrm{CE}}\right]^{2}\right. \\
& \left.+\left[\frac{-1}{\left(C_{\mathrm{E}}-C_{\mathrm{Pe}}\right)} \times W_{\mathrm{CT}}\right]^{2}\right\}^{\frac{1}{2}},
\end{aligned}
$$

where $W$ is the total uncertainty or error fraction related to each component, and $W_{\mathrm{CPe}}, W_{\mathrm{CE}}$, and $W_{\mathrm{CT}}$ are the uncertainty in the pre-event, event and total stream water, respectively. The uncertainties related to each component are computed by multiplying the standard deviations by $t$ values from the Student's $t$ distribution at the confidence level of $70 \%$ (Genereux, 1994).

\subsection{Estimation of mean residence time}

The mean residence time of stream water in a catchment is commonly computed using lumped parameter black box models described in Maloszewski and Zuber (1982). However, the application of this method to short data records and coarse spatial and temporal sampling leads to inaccurate estimates of parameters and tracer mass imbalance if the timescale of residence time distribution is larger than the input data (McGuire and McDonnell, 2006).

Hence, due to the short record length and coarse frequency of spatial and temporal tracer sampling, in this study the mean residence time is estimated based on the sine wave approach fitting the seasonal $\delta^{18} \mathrm{O}$ variation in precipitation and streamflow (e.g. McGuire et al., 2002; Rodgers et al., 2005a; Tetzlaff et al., 2007b). The method gives indicative first approximation estimates of mean residence times (Soulsby et al., 2000; Rodgers et al., 2005a). The predicted $\delta^{18} \mathrm{O}$ can be defined as

$\delta=C_{\mathrm{o}}+A[\cos (c t-\varphi)]$, 
where $\delta$ is the predicted $\delta^{18} \mathrm{O}[\% \mathrm{o}]$ composition, $C_{\mathrm{o}}$ is the weighted mean annual measured $\delta^{18} \mathrm{O}[\% \mathrm{o}]$, A is the annual amplitude of predicted $\delta^{18} \mathrm{O}[\% \circ], c$ is the angular frequency constant $\left(0.017214 \mathrm{rad} \mathrm{d}^{-1}\right), t$ is the time in days after the start of the sampling period and $\varphi$ is the phase lag of predicted $\delta^{18} \mathrm{O}$ in radians. Furthermore, Eq. (9) can be evaluated using sine and cosine terms in a periodic regression analysis (Bliss, 1970) as

$\delta=C_{\mathrm{o}}+\beta_{\mathrm{cos}} \cos (c t)+\beta_{\mathrm{sin}} \sin (c t)$.

The estimated regression coefficients $\beta_{\cos }$ and $\beta_{\sin }$ are used to compute the amplitude in input and output signals $\left(A=\sqrt{\beta^{2} \cos +\beta^{2} \sin }\right)$, and consequently the phase $\operatorname{lagtan} \varphi=\left|\frac{\beta_{\sin }}{\beta_{\cos }}\right|$.

The mean residence time from the fitted sine wave in input and output signals was estimated as

$T=c^{-1}\left[\left(\frac{A_{2}}{A_{1}}\right)^{-2}-1\right]^{0.5}$,

where $T$ is the mean residence time [d], $A_{1}$ is the amplitude of precipitation $\delta^{18} \mathrm{O}[\% \mathrm{o}], A_{2}$ is the amplitude of streamflow $\delta^{18} \mathrm{O}[\%$ ] , and $c$ is defined in Eq. (9).

\section{Results and discussion}

\subsection{Meteoric water lines}

The plot representing the relationship between $\delta^{18} \mathrm{O}$ and $\delta^{2} \mathrm{H}$ isotopic composition for precipitation is shown in Fig. 3. The spring and river water isotopic compositions are also plotted in the same figure for comparison. The spatial distribution of $\delta^{18} \mathrm{O}$ and $\delta^{2} \mathrm{H}$ compositions of precipitation varies considerably along the elevation gradient. Fana Choke station located at the highest elevation has more negative isotope compositions than the Yewla lower altitude station. The air masses lifted at the higher altitude with lower air temperature and higher relative humidity, due to orographic effects, could be possible reasons for the elevation-dependent variations of isotope composition. The difference in the isotopic composition at these two stations was evaluated using the Wilcoxon signed rank statistical test. The test results show that the difference in the isotopic values at the two locations is statistically significant $(p=0.020)$ evaluated at the $95 \%$ confidence level. The scatter of the isotopic composition from the global meteoric water line might be related to the effect of the evaporation of falling rain drops, condensation in the cloud and different moisture sources over different seasons (Dansgard, 1964; Gat, 1996; Levin et al., 2009; Kebede and Travi, 2012). However, from the plot of the relationship between $\delta^{18} \mathrm{O}$ and $\delta^{2} \mathrm{H}$ isotopic composition for precipitation, the effect of evaporation is insignificant and plots along the local

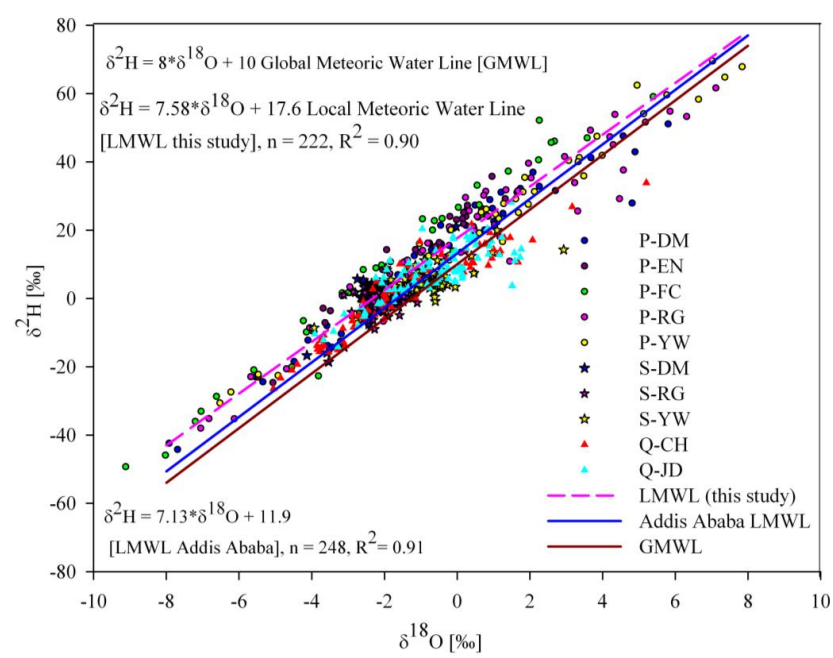

Figure 3. Relationship between $\delta^{18} \mathrm{O}$ and $\delta^{2} \mathrm{H}$ for precipitation, stream and spring water in the study area. The abbreviations in the legend are described in Table 2.

evaporation line. This means that the isotope values do not deviate from the local and global water lines.

The representation of the isotope values with the local meteoric water line was compared with that of the Addis Ababa Meteoric Water Line (MWL) produced using Global Network of Isotopes in Precipitation (GNIP) samples (Fig. 3). The relationships of $\delta^{18} \mathrm{O}$ and $\delta^{2} \mathrm{H}$ composition of the present study all exhibit an almost similar slope to that of the Addis Ababa station. However, it has a higher intercept/deuterium excess than the Addis Ababa GNIP station. The higher $d$ excess values $>10 \%$ in both Addis Ababa and the study area are attributed to land surface-atmosphere interaction through transpired moisture contribution (Gat et al., 1994).

Furthermore, it is shown that the precipitation waters with more positive isotopic values are derived from the winter and spring season precipitation, whereas those plotting at the more negative end of the LMWL are derived from summer precipitation. The river water isotopic values in the Chemoga and Jedeb catchments exhibit little variation along the LMWL. These variations indicate that the waters for both catchments derived mostly from the summer precipitation. The spring waters at Debre Markos and Rob Gebeya exhibit negative isotopic composition as compared to Yewla, which is located towards the positive end of the LMWL.

\subsection{Spatio-temporal variation of isotope composition in precipitation, spring water and streamflow}

\subsubsection{Isotope composition of precipitation}

The results of the measured isotopic composition of precipitation samples exhibit marked spatial and seasonal variations (Fig. 4). The precipitation at Yewla station (lowest altitude) shows less negative $\delta^{18} \mathrm{O}$ and $\delta^{2} \mathrm{H}$ values in contrast 

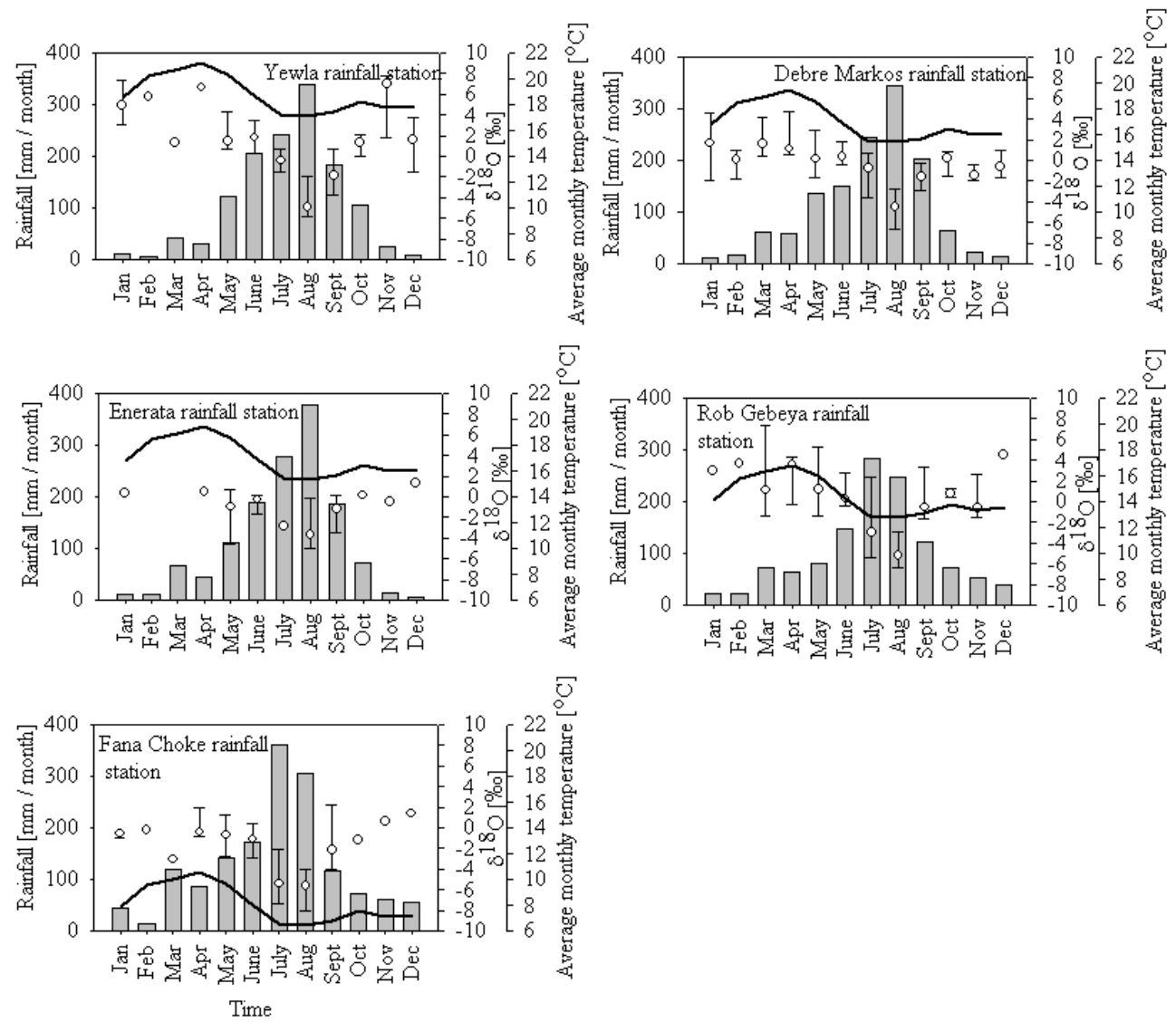

Figure 4. Spatial and intra-annual variations of average monthly precipitation, temperature and isotopic composition of $\delta^{18} \mathrm{O}$ in precipitation. The error bar of the isotopic measurements stand for the standard deviation. Missing error bars for some months are due to limited isotope samples. The grey bar, black solid line and open circle with error bar are the precipitation, temperature and isotopic composition, respectively. For the isotopic composition, the open circle and the lower and upper error bars indicate the median and the 25th and 75th percentiles for the raw (non-weighted) precipitation isotope sample data, respectively.

to more negative isotopic composition at Fana Choke station (highest altitude). This shows the anticipated isotopic composition influenced by the altitude effect (Dansgaard, 1964; Rozanski et al., 1993). Nevertheless, the altitude effect varies temporally over different seasons depending on the moisture source, amount and trajectories of air mass bringing precipitation and local meteorological settings (Aravena et al., 1999). For instance, the seasonal isotopic composition relationship with elevation along the gradient during different seasons shows more negative values of isotopic composition at higher altitudes (Fig. 5). The altitude effect accounts for -0.12 and $-0.58 \%$ per $100 \mathrm{~m}$ increase in altitude for $\delta^{18} \mathrm{O}$ and $\delta^{2} \mathrm{H}$, respectively. This is consistent with an earlier finding by Kebede and Travi (2012), who found more negative values of $\delta^{18} \mathrm{O}$ by $-0.1 \%$ oper $100 \mathrm{~m}$ in the higher elevations of the Upper Blue Nile plateau.

The $\delta^{18} \mathrm{O}$ and $\delta^{2} \mathrm{H}$ composition is also affected by the precipitation amount effect (Dansgaard, 1964; Rozanski et al., 1993). Figures 6 and 7 illustrate the $\delta^{18} \mathrm{O}$ and $\delta^{2} \mathrm{H}$ composition of precipitation at sampling stations, which show moder- ate regression coefficients ranging from $\left(R^{2}=0.36-0.68, p\right.$ value varies from 0.001 to 0.007$)$ for precipitation and $\left(R^{2}=\right.$ $0.26-0.39, p$ value varies from 0.001 to 0.007 ) for temperature. This suggests that the amount effect at each sampling location is important for the variation in isotopic composition in the area in addition to other factors. However, our results are in contrast to the earlier studies by Kebede (2004) and Kebede and Travi (2012), who reported weak relationships between rainfall amounts and isotopic compositions in the northwestern Ethiopian plateau.

Moreover, multiple linear regression models are used to show the effect of monthly precipitation and mean monthly temperature on $\delta^{18} \mathrm{O}$ and $\delta^{2} \mathrm{H}$ isotopic composition of precipitation in the Chemoga and Jedeb catchments, respectively. The multiple regression models for $\delta^{2} \mathrm{H}$ composition in the Chemoga and Jedeb catchments are described as

- $\delta^{2} \mathrm{H}=-0.096 P+2.093 T+0.736\left(R^{2}=0.74, n=\right.$ $28, p=0.001$ for precipitation and $p=0.121$ for temperature) in the Chemoga catchment, and 

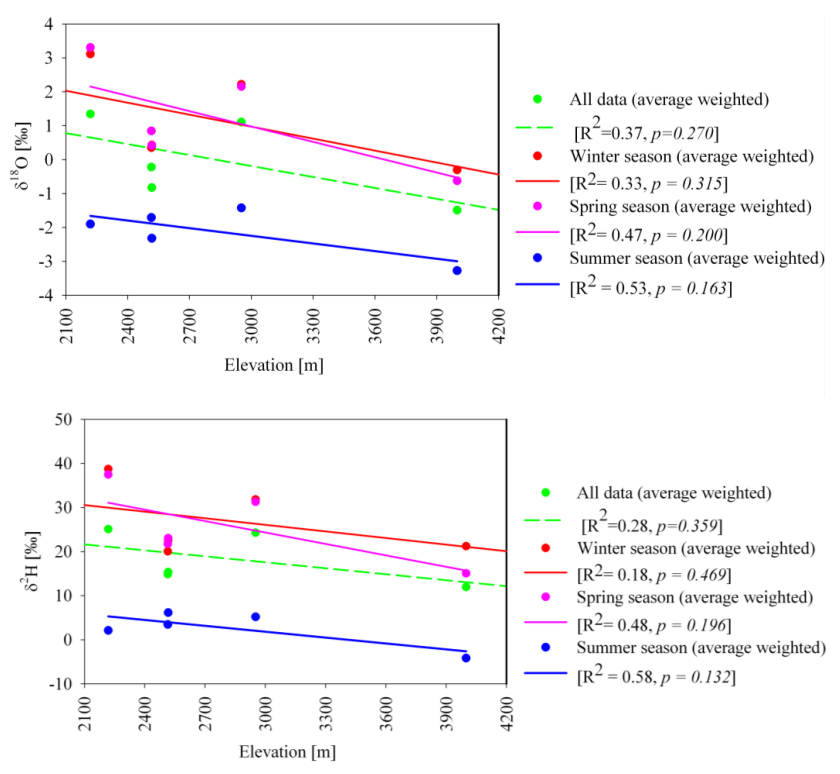

Figure 5. Relationships between average and seasonal amount weighted isotopic composition of precipitation with elevation at five precipitation sampling stations.

$-\delta^{2} \mathrm{H}=-0.116 P+2.414 T-1.374\left(R^{2}=0.76, n=28\right.$, $p=0.001$ for precipitation and $p=0.175$ for temperature evaluated at the $5 \%$ significance level) in the Jedeb catchment,

where $P$ in the regression equation is the monthly precipitation (mm month ${ }^{-1}$ ) and $T$ is the mean monthly average temperature $\left({ }^{\circ} \mathrm{C}\right)$. These results from the multiple linear regression models also show that the amount effect has a more dominant role in the variations in the isotopic composition in the study area than the temperature effect.

The seasonal variations in the isotopic composition of precipitation are observed among the stations. For instance, the winter seasonal mean weighted $\delta^{18} \mathrm{O}$ composition of precipitation has, with a value of $-0.41 \%$, a negative isotope value at Fana Choke at the higher altitude and has positive isotope values of $3.08 \%$ at the lowest altitude (Yewla station). During the spring season the mean weighted $\delta^{18} \mathrm{O}$ composition is $-0.62 \% o$ at Fana Choke and $3.3 \%$ at Yewla. Similarly, during summer a more negative isotopic composition of $-3.28 \%$ is observed at Fana Choke and a relatively less negative composition $-1.9 \%$ is observed at Yewla.

In the Chemoga catchment the mean weighted seasonal isotopic compositions of $\delta^{18} \mathrm{O}$ and $\delta^{2} \mathrm{H}$ in precipitation during winter, spring and summer are 0.72 and $24.85 \%$, 0.86 and $23.71 \%$ o, and -2.09 and $2.36 \%$, respectively. Obviously the summer seasonal isotopic compositions in both $\delta^{18} \mathrm{O}$ and $\delta^{2} \mathrm{H}$ have more negative values than in the winter and spring seasons owing to the different moisture sources and the local meteorological settings like precipitation, air temperature, and humidity. In comparison to the Chemoga catchment, the mean weighted seasonal isotopic composition in the Jedeb
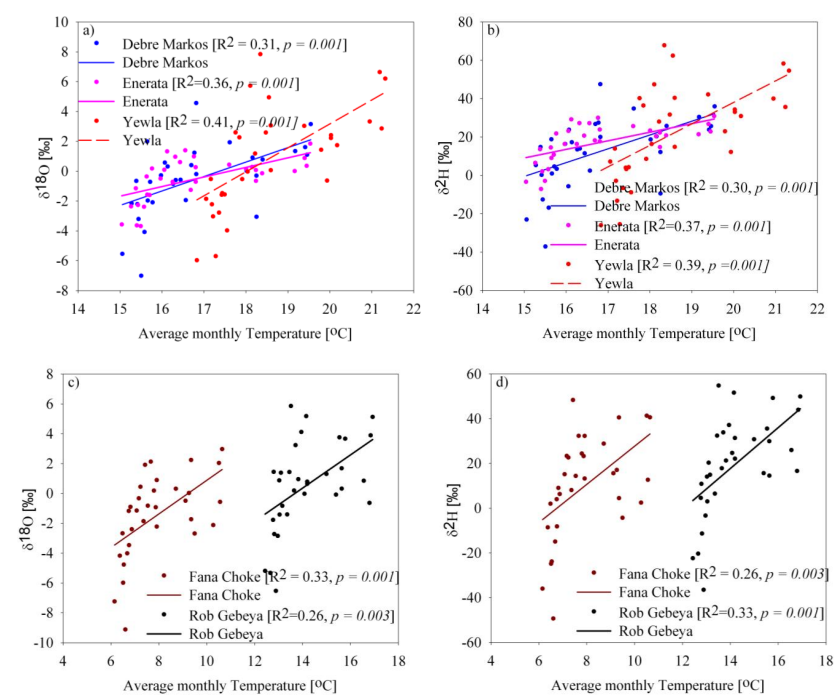

Figure 6. Relationships between amount-weighted isotopic composition of precipitation samples at different stations with monthly average air temperature over the investigation period.
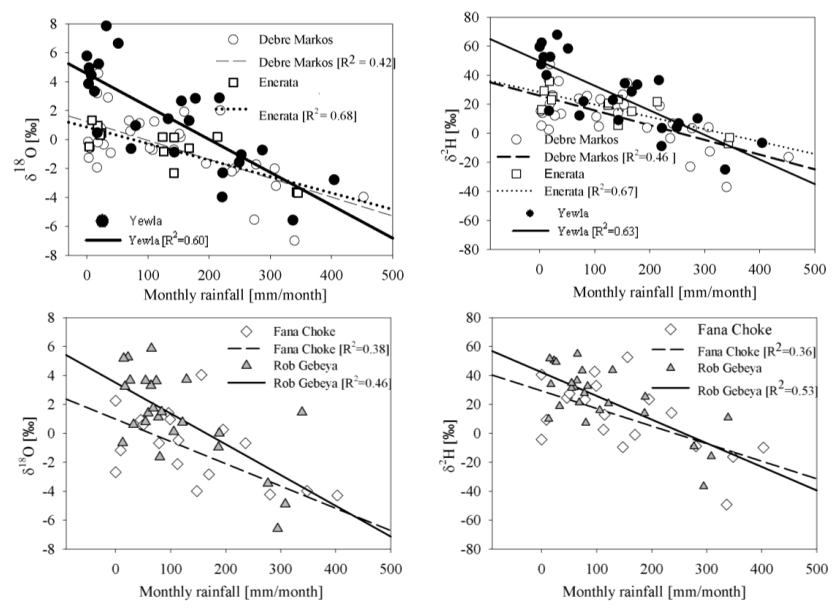

Figure 7. Relationship between amount-weighted isotopic composition of precipitation samples at different stations with monthly precipitation amounts at respective stations during the investigation period.

catchment shows consistently less negative $\delta^{18} \mathrm{O}$ and $\delta^{2} \mathrm{H}$ isotopic values of 1.48 and $29.23 \%$ o, 1.65 and $28.30 \%$, and -1.93 and $2.74 \%$ in the winter, spring and summer seasons, respectively. This implies that the less negative isotopic values of precipitation are likely related to different temperatures and altitudes in the Jedeb catchment.

\subsubsection{Isotope composition of spring water}

The isotopic composition of spring water at the three locations shows distinct variability ranging from -8.5 to $13.5 \%$ o and -4.1 to $2.9 \%$ for $\delta^{2} \mathrm{H}$ and $\delta^{18} \mathrm{O}$, respectively (see Table 3). The spring waters of Debre Markos (at an elevation 
of 2339 m a.s.1.) and Rob Gebeya (at $2820 \mathrm{~m}$ a.s.l.) exhibit more negative isotopic compositions as compared to the isotopic composition of spring water of Yewla (at an elevation of $2255 \mathrm{~m}$ a.s.l.), which showed less negative isotopic compositions. The mean raw isotopic composition of spring water indicates a wide range at the three locations. The observed mean isotopic variation at the three locations ranged from -0.6 to $5.5 \%$ ofor $\delta^{2} \mathrm{H}$ and -2.1 to $-0.7 \%$ or for $\delta^{18} \mathrm{O}$. The mean values for $\delta^{18} \mathrm{O}$ at Debre Markos and Rob Gebeya exhibit a similar isotopic composition of $-2.1 \%$.

It is interesting that the isotopic compositions for the springs at Debre Markos and Rob Gebeya follow similar patterns and exhibit no major distinction in their isotope composition (Fig. 8). This indicates that the spring water isotopic composition for both springs derived from the same altitude range of the recharge area or different areas with the same mean elevation. The mean seasonal isotopic variations at the three spring locations during the winter season ranged between -0.2 and $4.7 \%$, and between -2.1 and $-0.7 \%$ for $\delta^{2} \mathrm{H}$ and $\delta^{18} \mathrm{O}$, respectively. During the spring season the mean seasonal isotopic values ranged between -2.6 and $6.3 \%$, and between -2.4 and $-0.5 \%$ for $\delta^{2} \mathrm{H}$ and $\delta^{18} \mathrm{O}$, respectively. During the summer season the mean seasonal isotopic variations ranged between 0.2 and $5.9 \%$, and between -2.0 and $-0.9 \%$ for $\delta^{2} \mathrm{H}$ and $\delta^{18} \mathrm{O}$, respectively. This implies that the isotopic values are more negative during the spring season and positive during the winter and summer seasons.

The mean winter and spring seasonal $\delta^{18} \mathrm{O}$ isotopic compositions of precipitation exhibit values greater than $0 \%$ for all five stations (see Sect. 4.2.1), except the more negative values at the highest altitude (Fana Choke station). In contrast to the precipitation signature during these seasons, the spring waters exhibit a more negative isotopic composition. This suggests that the spring water during the winter and spring seasons is merely derived from summer season precipitation. The highlands seem to be the main recharge area of the spring (see Fig. 10). This shows that the winter and spring season precipitation does not contribute significantly to recharging the groundwater. This finding is in agreement with the previous studies in the region (e.g. Kebede et al., 2003; Kebede and Travi, 2012). They pointed out that during the dry and spring seasons most of the water is evaporated without contributing to the groundwater recharge. Furthermore, the fact that the spring water isotope signal is more damped compared to the river water isotope signal gives a hint that the spring water could be a mixture of old water components having longer residence times than the river water.

\subsubsection{Isotopic composition of river water}

The mean volume weighted $\delta^{18} \mathrm{O}$ isotope value for the Chemoga catchment was $-1.4 \%$, and the $\delta^{2} \mathrm{H}$ composition was $2.7 \%$. During the winter or dry seasons the mean iso-
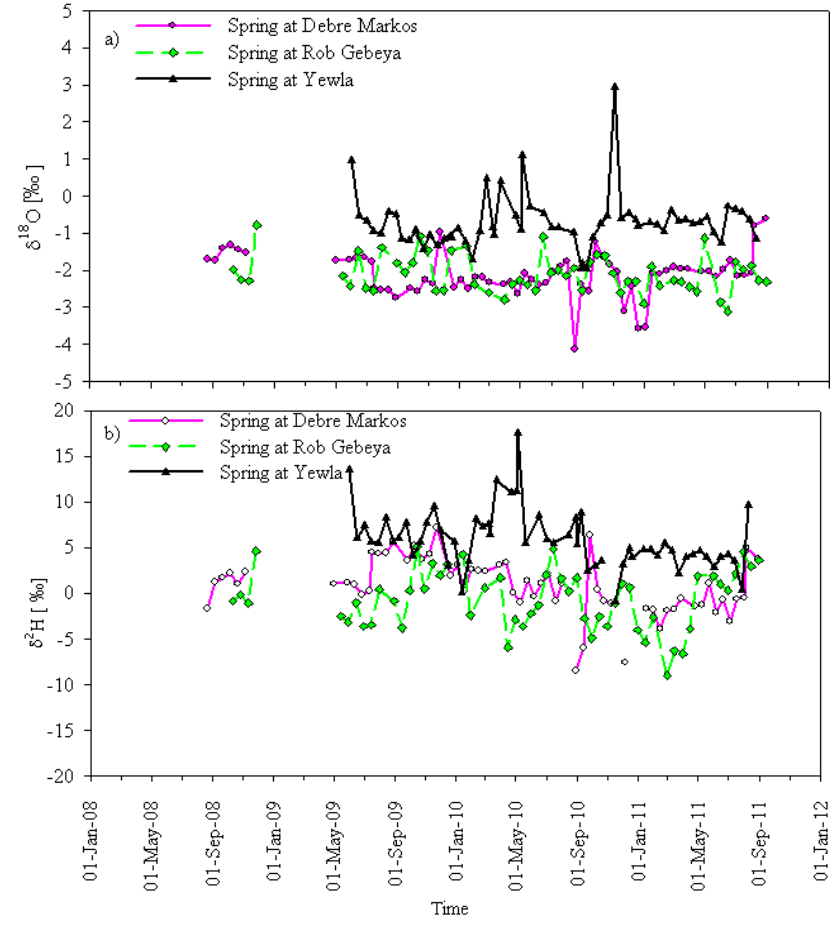

Figure 8. Temporal isotopic variability of three different nonweighted spring water samples: (a) $\delta^{18} \mathrm{O}$ and (b) $\delta^{2} \mathrm{H}$ composition over different investigation periods.

tope compositions were 0.1 and $6.2 \%$ for $\delta^{18} \mathrm{O}$ and $\delta^{2} \mathrm{H}$, respectively. The mean isotope compositions during the spring or little rainy seasons were -0.7 and $11.7 \%$ for $\delta^{18} \mathrm{O}$ and $\delta^{2} \mathrm{H}$, respectively. The summer or main rainy season mean isotope compositions were -2.3 and $-3.3 \%$, respectively. This implies that the summer isotope composition always exhibited more negative values than the winter and spring seasons.

In the Jedeb catchment the mean volume weighted $\delta^{18} \mathrm{O}$ and $\delta^{2} \mathrm{H}$ compositions in river water are -0.6 and $4.9 \%$, respectively. For the dry season (winter) the mean $\delta^{18} \mathrm{O}$ and $\delta^{2} \mathrm{H}$ values were 0.12 and $6.3 \%$ o, respectively. For the little rainy season (spring) the mean $\delta^{18} \mathrm{O}$ and $\delta^{2} \mathrm{H}$ values were -0.3 and $8.5 \%$, and for the summer long rainy season -1.3 and $1.7 \%$, respectively. These results show that in all seasons except for the $\delta^{2} \mathrm{H}$ composition in the spring season, the Jedeb river water exhibits more positive isotope composition as compared to the Chemoga river. Moreover, the damped response of the isotope signature during the summer season in the Jedeb river as compared to the Chemoga river might suggest that the differences in catchment storage have a relatively higher mean residence time.

Field visits during three years also supportedthe hypothesis that during the dry season in the Jedeb catchment the flow was sustained, while in the Chemoga catchment the dry season flow in the river was occasionally not sustained. Thus, the two catchments have different storage capacities. This 
Table 3. Mean, range and standard deviation of $\delta^{2} \mathrm{H}$ and $\delta^{18} \mathrm{O}$ [\%o, VSMOW] amount-weighted concentration for precipitation and volume weighted for discharge and non-weighted for spring water during different investigation periods.

\begin{tabular}{|c|c|c|c|c|c|c|c|c|}
\hline \multirow{2}{*}{ Description } & \multicolumn{2}{|c|}{$\begin{array}{c}\text { Mean } \\
{[\% \text {, VSMOW] }}\end{array}$} & \multicolumn{2}{|c|}{$\begin{array}{c}\text { Minimum } \\
{[\%,, \text { VSMOW }]}\end{array}$} & \multicolumn{2}{|c|}{$\begin{array}{c}\text { Maximum } \\
{[\%,, \text { VSMOW] }}\end{array}$} & \multicolumn{2}{|c|}{$\begin{array}{c}\text { Standard } \\
\text { deviation } \\
{[\%,, \text { VSMOW }]}\end{array}$} \\
\hline & $\delta^{2} \mathrm{H}$ & $\delta^{18} \mathrm{O}$ & $\delta^{2} \mathrm{H}$ & $\delta^{18} \mathrm{O}$ & $\delta^{2} \mathrm{H}$ & $\delta^{18} \mathrm{O}$ & $\delta^{2} \mathrm{H}$ & $\delta^{18} \mathrm{O}$ \\
\hline Precipitation at Yewla & 22.5 & 1.0 & -25.5 & -5.7 & 67.8 & 7.8 & 24.7 & 3.5 \\
\hline Precipitation at Debre Markos & 12.3 & -0.6 & -37.1 & -7.0 & 74.6 & 4.6 & 18.4 & 2.4 \\
\hline Precipitation at Enerata & 15.4 & -0.8 & -7.1 & -3.7 & 29.2 & 1.3 & 11.9 & 1.7 \\
\hline Precipitation at Rob Gebeya & 23.0 & 1.0 & -36.5 & -6.5 & 54.8 & 5.9 & 21.8 & 3.1 \\
\hline Precipitation at Fana Choke & 8.5 & -1.8 & -49.3 & -9.1 & 48.3 & 2.2 & 25.5 & 3.0 \\
\hline Chemoga catchment precipitation & 15.5 & -0.4 & -29.8 & -6.4 & 40.2 & 3.4 & 16.7 & 2.2 \\
\hline Jedeb catchment precipitation & 18.3 & 0.13 & -28.4 & -6.1 & 45.9 & 4.4 & 18.6 & 2.5 \\
\hline Chemoga discharge & 2.7 & -1.4 & -15.5 & -3.9 & 19.8 & 0.8 & 9.2 & 1.5 \\
\hline Jedeb discharge & 4.9 & -0.6 & -3.3 & -3.5 & 13.1 & 0.8 & 4.6 & 1.1 \\
\hline Yewla spring water & 5.7 & -0.7 & -8.0 & -3.9 & 13.5 & 2.9 & 4.0 & 0.9 \\
\hline Debre Markos spring water & 0.1 & -2.1 & -8.5 & -4.1 & 7.2 & -0.6 & 5.8 & 0.6 \\
\hline Rob Gebeya spring water & -0.6 & -2.1 & -9.0 & -3.1 & 5.1 & -0.8 & 3.3 & 0.5 \\
\hline
\end{tabular}

in turn seems to be related to the differences in hydrologic behaviour (see Fig. 9). A water balance study by Tekleab et al. (2011) in these catchments has also shown their hydrological differences in terms of partitioning the available water on an annual timescale. The plot of the annual evaporation ratio (the ratio of mean annual evaporation to mean annual precipitation) versus the aridity index (the ratio of mean annual potential evaporation to mean annual precipitation) in a Budyko curve demonstrated a higher evaporation ratio in the Chemoga catchment than in the Jedeb catchment.

Figure 9 presents the temporal variations in $\delta^{18} \mathrm{O}$ and $\delta^{2} \mathrm{H}$ for the Chemoga and Jedeb catchments. In the figure the isotope composition streamflow during the main rainy season reflects damped characteristics (decreases in the amplitude of the streamflow isotope signals) as compared to the fluctuations in precipitation as were observed by e.g. McDonnell et al. (1990), Buttle (1994), and Soulsby et al. (2000). These investigations indicate that the damping behaviour of the isotope signal in streamflow is due to the fact that the preevent or old water component of the groundwater is a mixture of many past precipitation events and resulted in an isotopic concentration which is higher than the precipitation composition during storm events. The same holds true during summer months, when rainfall generates the highest flows; in the hydrological year 2010 at both catchments, the isotope composition of river water exhibits a damped response as compared to the precipitation responses (Fig. 9 inset figures).

\subsection{Potential moisture source areas for the study area}

Table 3 presents the mean, minimum, maximum and standard deviation of the amount-weighted precipitation and volumeweighted discharge data and the non-weighted composition for spring water. It demonstrates that more negative isotopic compositions values are observed during the main rainy season from June to September and that the less negative values are observed during the winter and spring seasons. This is obviously related to the multiple moisture sources (e.g. the Atlantic-Congo vegetation Sudd swamp, and the Indian Ocean) and to the local meteorological processes (e.g. localised precipitation, air temperature, and humidity) (Kebede and Travi, 2012).

Seasonal variations in the isotopic composition of different water samples are shown in Fig. 10. The isotope values in different seasons might suggest different potential moisture sources bringing precipitation into the study area. These different moisture sources are investigated by mapping the potential source areas of precipitation for different seasons. Figure 11 presents these source areas of precipitation for different seasons, whereby the starting points of the trajectories in the study area were computed using the HYSPLIT (Hybrid Single Particle Lagrangian Integrated Trajectory) model developed by NOAA (National Oceanic and Atmospheric Administration) at the Air Resources Laboratory (www.arl.noaa.gov/HYSPLIT_info.php). The model computes the trajectories by tracing back an air package for 14 days in different seasons.

It is shown that during the three seasons the source areas for starting points of moisture trajectories into the study area are different. During the main rainy season, i.e. the summer, the Atlantic Ocean, Indian Ocean, the White Nile and the Congo basin are the potential source areas of precipitation in the study area. However, in the spring and winter seasons, the potential source areas of moisture origin that are responsible for generating the little precipitation in study area are the Arabian Sea-Mediterranean Sea and to some extent the Indian Ocean. These results are in agreement with the 

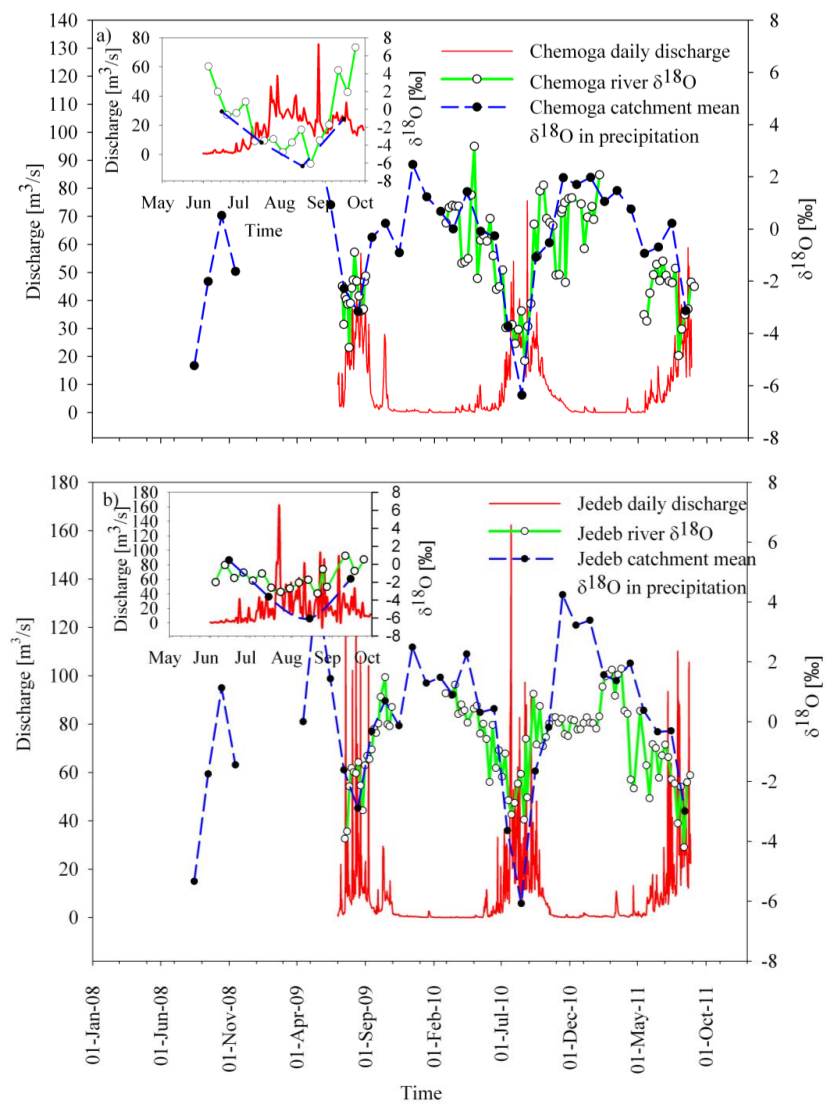

Figure 9. Temporal variations in $\delta^{18} \mathrm{O}$ and $\delta^{2} \mathrm{H}$ composition in precipitation and river discharge along with the daily flow rate for (a) the Chemoga catchment and (b) the Jedeb catchment. The inset figures are the details for summer season discharge and isotope composition for precipitation and streamflow for the hydrological year 2010.

earlier studies with regard to the source areas from the Atlantic Ocean, Indian Ocean, and the Congo basin (e.g. Levin et al., 2009; Kebede and Travi, 2012).

To date many research findings have not reached a consensus on the origin of common moisture source areas to the northern Ethiopian highlands. Mohamed et al. (2005) indicated that the moisture flux for the northern Ethiopian plateau has mainly Atlantic origin. However, a recent moisture transport study by Viste and Sorteberg (2013) in the Ethiopian highlands reported that the moisture flow from the Gulf of Guinea, the Indian Ocean and from the Mediterranean region across the Red Sea and the Arabian Peninsula are identified as the main sources of moisture transport in the region. According to their study, the largest contribution to the moisture transport into the northern Ethiopian highland was attributed to the air travelling from the Indian Ocean and from the Mediterranean region across the Red Sea and the Arabian Peninsula.
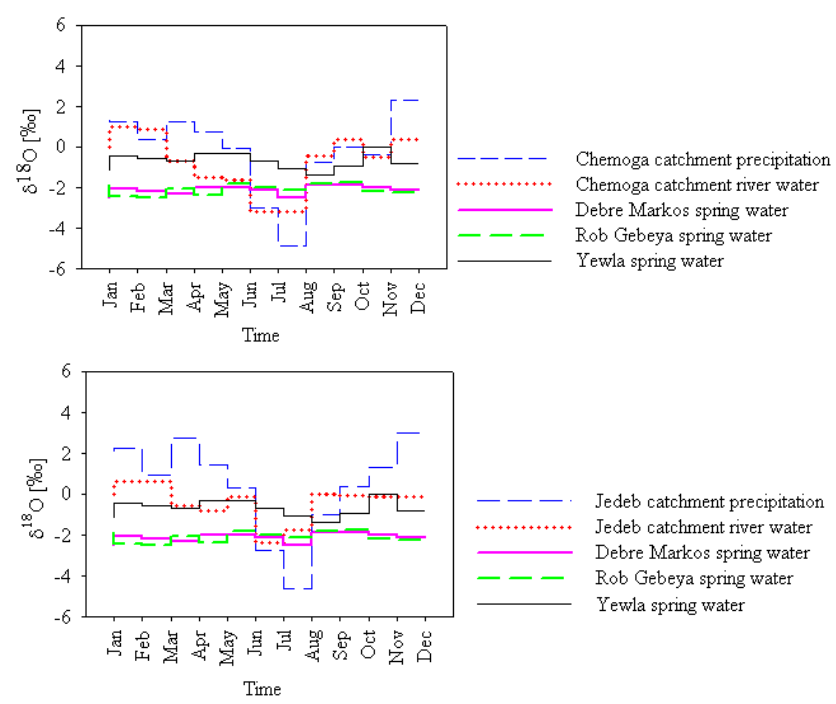

Figure 10. Monthly $\delta^{18} \mathrm{O}[\%$ ] isotopic variation in amountweighted precipitation, volume-weighted discharge and nonweighted spring water; (a) Chemoga and (b) Jedeb catchment for the period July 2009-August 2011.

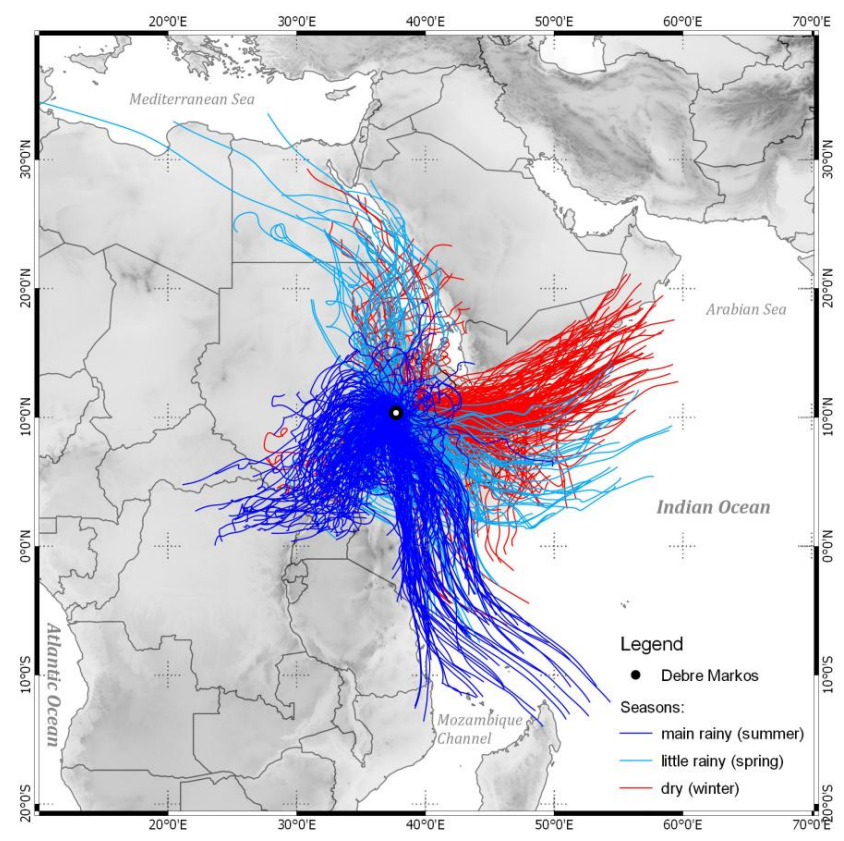

Figure 11. Potential source areas of precipitation to the study area in different seasons. Lines indicate the starting points of 14-day backward calculated trajectories. The black dot indicates the location of the study area.

\subsection{Hydrograph separation on a seasonal timescale}

The results of the two-component seasonal hydrograph separations reveal that the event water fraction is more dominant than the pre-event component in both catchments, in particular during the rainy season (Fig. 12). The proportion of the 
Table 4. Proportion of runoff components in the Chemoga and Jedeb catchments during the wet season.

\begin{tabular}{lrrrrr}
\hline \multirow{2}{*}{ Month } & \multicolumn{2}{c}{ Chemoga catchment } & & \multicolumn{2}{c}{ Jedeb catchment } \\
\cline { 2 - 3 } \cline { 6 - 6 } & $\begin{array}{r}\text { Event } \\
\text { water (\%) }\end{array}$ & $\begin{array}{r}\text { Pre-event } \\
\text { water (\%) }\end{array}$ & & $\begin{array}{r}\text { Event } \\
\text { water }(\%)\end{array}$ & $\begin{array}{r}\text { Pre-event } \\
\text { water (\%) }\end{array}$ \\
\hline Jul 2009 & 94.59 & 5.41 & & 96.46 & 3.54 \\
Aug 2009 & 79.36 & 20.64 & & 68.44 & 31.56 \\
Sep 2009 & 32.03 & 67.97 & & 69.34 & 30.66 \\
Jun 2010 & 57.45 & 42.55 & & 89.30 & 10.70 \\
Jul 2010 & 99.72 & 0.28 & & 58.28 & 41.72 \\
Aug 2010 & 64.62 & 35.38 & & 34.91 & 65.09 \\
Sep 2010 & 38.69 & 61.31 & & 31.23 & 68.77 \\
Jun 2011 & 67.67 & 32.33 & & 67.56 & 32.44 \\
Jul 2011 & 88.75 & 11.25 & & 62.06 & 37.94 \\
Aug 2011 & 89.88 & 10.12 & & 64.86 & 35.14 \\
\hline
\end{tabular}

summer (rainy season) monthly variation in the event water component varies from 32 to $99 \%$ with an average of $71 \%$ in the Chemoga catchment and from 31 to $96 \%$ with an average of $64 \%$ in the Jedeb catchment over three different wet seasons of the investigation period (Table 4). Obviously, preevent water is almost the sole contribution during the other seasons.

The average proportions of the different runoff components due to different end members (i.e. the whole dry season average concentration and the average of dry and little rainy season concentrations) exhibit a higher proportion of event water but vary from 62 to 67 and from 33 to $38 \%$ for the pre-event water in the Chemoga catchment. In the Jedeb catchment the event water component varies from 52 to $55 \%$ and the pre-event water varies from 45 to $48 \%$, respectively, due to different end members. These relatively small ranges of flow component contribution give a hint of the robustness of the method.

The proportion of the new water during the three wet seasons in both catchments is more towards the rising limb of the hydrograph. This implies that the new water component is generated via surface hydrological flow pathways in both of the catchments, and has a greater proportion than the preevent component. Surface runoff generation starts immediately after the rainfall event in agricultural fields, in grazing lands and on bare lands. The existing gully formation as a result of severe erosion from different land use also corroborates the results of the isotope study, which shows the dominance of the event water proportion in these catchments. This is also supported by the observed flashy behaviour of small catchments (Temesgen et al., 2012). However, it is noted that the pre-event water dominates after the main event water peak.

Furthermore, it can be assumed that the high percentage of event water in both catchments is due to the low infiltration rate and the compaction of the top soil in the agricultural lands. Research in the vicinity of these catchments also suggests that the effect of a plough pan due to long
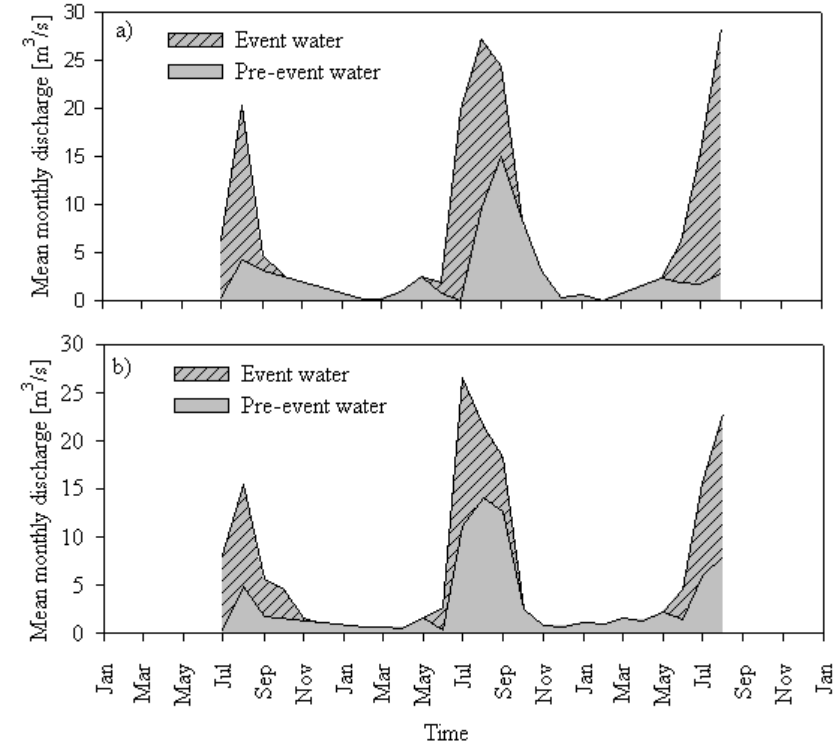

Figure 12. Two-component hydrograph separations using $\delta^{18} \mathrm{O}$ as a tracer in the (a) Chemoga and (b) Jedeb meso-scale catchments on a seasonal timescale over the period July 2009-August 2011.

years of ploughing activities reduces the infiltration capacity of the soil (Temesgen et al., 2012). The effect of topography, soil physical parameters and land degradation could also be another factor in the large proportion of the event water component (Teferi et al., 2013). Nonetheless, during winter (dry season) and spring (small rainy season) the river water at both catchments is solely derived from the groundwater recharged during the rainy (summer) season. Similar studies in the US from small agriculturally dominated catchments showed that event water has a large proportion of runoff components due to low infiltration rates of agriculturally compacted soils (Shanley et al., 2002).

Past studies in different regions showed that the pre-event water is the dominant runoff component during the event (e.g. Sklash and Farvolden, 1979; Pearce et al., 1986; McDonnell, 1990; Mul et al., 2008; Hrachowitz et al., 2011a; Munyaneza et al., 2012). However, the results from the present study showed that event water is the dominant runoff component. The possible reasons could be an agriculturally dominated catchment with a high soil erosion affected area, steep slopes (e.g. varying between $2 \%$ in the lower part of the catchment and more than $45 \%$ in the upper part) and high seasonality of climate; the event water proportion is the dominant runoff component during the wet season on the seasonal timescale. Thus, due to these factors, the event water proportion is the dominant runoff component during the wet season on the seasonal timescale. 


\section{Uncertainty analysis of the hydrograph separations}

Table 5 presents the results of the uncertainty analysis for the seasonal hydrograph separation at the $70 \%$ (approximately one standard deviation) confidence interval. The isotope concentrations in the month of February (low flow) preevent end member were selected for the uncertainty estimation over the whole wet season. The uncertainty results from this end member concentration are relatively low compared to the sensitivity analysis made for the different pre-event end member concentrations.

The average uncertainty terms arising from the pre-event, event and river water for the three wet season periods accounted for 61,7 , and $32 \%$ for the Chemoga catchment and 51,4 , and $45 \%$ for the Jedeb catchment. This suggests that most of the uncertainty stems from the event water component. Genereux (1994) pointed out that the greater uncertainty can mainly be attributed to the proportions that contribute the higher runoff components.

The error in hydrograph separation originates from different sources (see Uhlenbrook and Hoeg, 2003 for details). Based on the uncertainty results, the proportion of the different components using different pre-event end member concentrations gives only a range of values, not the exact number. Thus, due to spatial and temporal variation in the end member concentrations, the classical hydrograph separations methods give only a qualitative description of the runoff components and their variable contributions in time (Uhlenbrook and Hoeg, 2003).

\subsection{Estimation of mean residence times}

Preliminary estimation of mean residence time was obtained using the model described in Eqs. (9)-(11) and results are provided in Table 6 . Based on the seasonal variation in $\delta^{18} \mathrm{O}$ both in precipitation and streamflow, the mean residence times are estimated as 4.1 and 6.0 months in the Chemoga and Jedeb catchments, respectively (see Fig. 13). The goodness of fit of the observed streamflow output isotope signal is moderate, as is shown by the coefficients of determination ( $R^{2}$ varies from 0.47 to 0.66 ). The method is appropriate for the short record length and coarse frequency of spatial and temporal tracer sampling. Indeed, the method gives indicative first approximation estimates of mean residence times and the level of fit is in line with previous studies (Soulsby et al., 2000; Rodgers et al., 2005a). The results of short mean residence times in both catchments are in line with the hydrograph separations, which indicate more surface runoff generation than base flow contribution during the storm events in these steep headwater catchments.

The results of preliminary estimation of mean residence time are plausible and anticipated from steep agriculturally dominated catchments with little adoption of soil and water conservation measures, which enhance more surface runoff
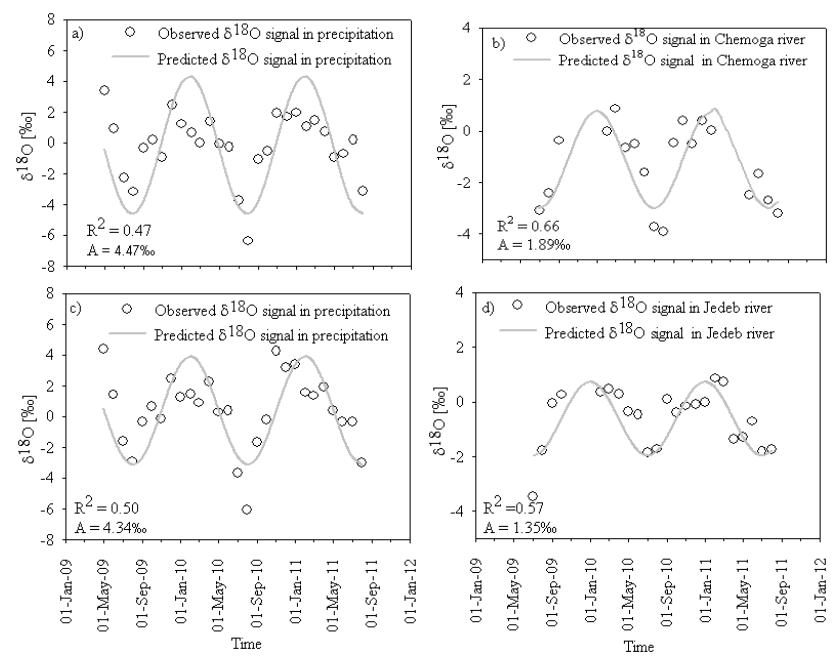

Figure 13. Fitted sine wave regression models to $\delta^{18} \mathrm{O}$ values for precipitation and river water (a) and (b) in the Chemoga, and (c) and (d) in the Jedeb river. Inside the figures, $R^{2}$ is the coefficient of determination, and " $\mathrm{A}$ " is the amplitude for the input and output isotope signals.

generation (Temesgen et al., 2012). Consequently, the surface condition or the responsiveness of the soil due to the plough pan effect influences the ability of the soil to infiltrate the given rainfall amount to recharge the groundwater system (Tekleab et al., 2013). Nonetheless, this result cannot be generalised to other regions with agriculturally dominated catchments. Other factors like the soil infiltration and retention conditions, slope, drainage network and other parameters and processes could also alter/influence the runoff generation mechanism. However, in these case study catchments, the overland flow is the dominant runoff component.

Furthermore, study in the northwestern Ethiopian plateau reported that the groundwater in the area is characterised by shallow and rapid circulation leading to a young age of the groundwater system, which may considered to be the cause of the drying out of groundwater wells after prolonged droughts (Kebede, 2004). However, the groundwater age distribution is not yet fully understood in the area, and needs further research.

The mean residence time in a catchment varies depending on topography, soil types, land cover, and geologic properties (McGlynn et al., 2003; Tetzlaff, et al., 2007a, 2009). The estimated mean residence times in this study are in agreement with similar meso-scale catchments around the world. For instance, Rodgers et al. (2005a) found a residence time of 6.8 months in the Scotland Feugh meso-scale catchment, which is dominated by responsive soils. In a similar isotope study in Scotland in a nested meso-scale catchment (the catchment area varies from 10 to $231 \mathrm{~km}^{2}$ ), the estimated mean residence time varies from 1 month to 14 months (Rodgers et al., 2005b). Uhlenbrook et al. (2002) found the residence times 
Table 5. Percentage of total uncertainty in event, pre-event and stream water concentrations during the wet season in the Chemoga and Jedeb catchments.

\begin{tabular}{lrrrrrrr}
\hline \multirow{2}{*}{ Month } & \multicolumn{3}{c}{ Chemoga catchment } & & \multicolumn{3}{c}{ Jedeb catchment } \\
\cline { 2 - 4 } \cline { 6 - 7 } & $\begin{array}{r}\text { Event } \\
\text { water (\%) }\end{array}$ & $\begin{array}{r}\text { Pre-event } \\
\text { water (\%) }\end{array}$ & $\begin{array}{r}\text { River } \\
\text { water }(\%)\end{array}$ & & $\begin{array}{r}\text { Event } \\
\text { water }(\%)\end{array}$ & $\begin{array}{r}\text { Pre-event } \\
\text { water }(\%)\end{array}$ & $\begin{array}{r}\text { River } \\
\text { water (\%) }\end{array}$ \\
\hline Jul 2009 & 96.90 & 0.02 & 3.08 & & 96.3 & 0.00 & 3.69 \\
Aug 2009 & 54.21 & 2.67 & 43.12 & & 25.6 & 3.34 & 71.05 \\
Sep 2009 & 41.37 & 58.63 & 0.00 & & 58.7 & 1.75 & 39.51 \\
Jun 2010 & 14.41 & 7.35 & 78.24 & & 76.2 & 0.13 & 23.64 \\
Jul 2010 & 72.80 & 0.00 & 27.20 & & 55.9 & 3.35 & 40.72 \\
Aug 2010 & 94.67 & 2.96 & 2.37 & & 44.5 & 9.25 & 46.23 \\
Sep 2010 & 11.00 & 10.21 & 78.79 & & 29.2 & 12.93 & 57.92 \\
Jun 2011 & 82.86 & 14.03 & 3.11 & & 36.6 & 3.00 & 60.43 \\
Jul 2011 & 67.72 & 0.29 & 31.99 & & 39.8 & 3.83 & 56.39 \\
Aug 2011 & 72.22 & 0.01 & 27.77 & & 42.7 & 3.16 & 54.15 \\
\hline Average & 61.00 & 9.00 & 30.00 & & 51.00 & 4.00 & 45.00 \\
\hline
\end{tabular}

Table 6. Amount-weighted mean precipitation and flow $\delta^{18} \mathrm{O}$ composition, estimated amplitude, phase lag $\varphi$ and mean residence time in the Chemoga and Jedeb catchments over the period July 2009-August 2011.

\begin{tabular}{lrrrr}
\hline & $\begin{array}{r}\text { Mean annual } \\
\text { measured } \delta^{18} \mathrm{O} \\
\text { [\%o, VSMOW] }\end{array}$ & $\begin{array}{r}\text { Amplitude } \\
{[\%, \text { VSMOW] }}\end{array}$ & $\begin{array}{r}\text { Phase lag } \\
\varphi \text { [radian] }\end{array}$ & $\begin{array}{r}\text { Mean residence } \\
\text { time [months] }\end{array}$ \\
\hline Chemoga catchment precipitation & -0.58 & 4.47 & 1.11 & 4.1 \\
Chemoga discharge & -1.34 & 1.89 & 0.01 & \multirow{2}{*}{6.0} \\
Jedeb catchment precipitation & 0.40 & 4.34 & 1.12 & 0.01 \\
Jedeb discharge & -0.70 & 1.35 & & \\
\hline
\end{tabular}

of 24 to 36 months for the shallow groundwater, and 6 to 9 years for the deep ground water in the Brugga $\left(40 \mathrm{~km}^{2}\right)$ black forest meso-scale catchment in Germany. Although the climate, topography, land use, soil and geology of the catchments in the present study are different from those of other investigated catchments, the estimated mean residence times are comparable.

It is apparent from the above discussion that the mean residence time is not directly dependent on the catchment size. However, the mean residence times might be longer for small headwater catchments (McGlynn et al., 2003). It is also noted that the mean residence time of a catchment is influenced by the heterogeneity in climatic setting, topography and geology (Hrachowitz et al., 2009), landscape controls, particularly soil cover (Soulsby et al., 2006), percent coverage responsive soil using catchment soil maps (Soulsby and Tetzlaff, 2008), and topography and soil drainage conditions in different geomorphic provinces (Tetzlaff et al., 2009). A recent study by Heidbüchel et al. (2012) showed that the mean residence time is better estimated using time-variable functions. Thus, the residence time depends not only on the catchment characteristics but also on time varying climate inputs. Nevertheless, investigating all these different controlling processes on mean residence time estimation was beyond the scope of the present study. Therefore, there is a need for further research that takes the influence of catchment heterogeneity and time varying input on the estimation of mean residence time into account in catchments of the Nile basin.

\section{Conclusions}

Characterisations of stable isotope composition of precipitation, spring and river water along different altitude gradients were undertaken with the aim of preliminarily estimating the mean residence time and runoff component contributions on a seasonal timescale. The results show that precipitation, stream and spring waters exhibit noticeable spatial and temporal variations in stable $\delta^{18} \mathrm{O}$ and $\delta^{2} \mathrm{H}$ composition in the study area.

The results further demonstrate that the meteoric water in the study area is influenced by the amount and to a lesser extent by the altitude and temperature effects. The climatic seasonality, which is dominated by different moisture sources, along with the local meteorological conditions play a significant role in the isotopic composition of rainfall in the area. 
The analyses of isotope results reveal the dominance of event water and short mean residence times in both of the catchments. From the point of view of managing the water resources and the importance of the available soil water for consumptive use of the crops, catchment management aiming at reducing overland flow/soil erosion and increasing soil moisture storage and recharge has paramount importance for the farmers residing in these catchments.

It should be noted that in the light of the data availability the estimated mean residence times and seasonal hydrograph separation represent first approximations. Consequently, for more reliable estimates of the mean residence times and runoff contributions there is a need for further research with finer resolution sampling during storm events and long-term isotope tracer data collection at different spatial and finer temporal scales (e.g. daily and hourly) that will improve our understanding of how these catchments function. It is noteworthy that the applied methods were used for the first time in the region that has critical regional importance regarding the water resources in the Nile. Thus, the results can be used as a baseline for further hydrological studies for a better understanding of the dominant runoff components in the future.

Acknowledgements. The study was carried out as a project within the integrated research programme "In search of sustainable catchments and basin-wide solidarities in the Blue Nile River Basin Hydrosolidarity", which was funded by the Foundation for the Advancement of Tropical Research (WOTRO) of the Netherlands Organisation for Scientific Research (NWO), UNESCO-IHE and Addis Ababa University. We also thank the Ethiopian Ministry of Water Resources and Energy for providing the hydrological data and the National Meteorological Agency for providing the weather data. We would like to thank Melesse Temesgen, who facilitated the data collection initially and made the precipitation sample collectors. We would also like to thank Solomon Takele, Lakachew Alemu, Limenew Mihrete, Mengistu Abate, Chekolech Mengistie, and Derseh Gebeyehu for isotope sample collection of precipitation, spring and stream waters. Our thanks extend to Jorge Valdemar Zafra Cordova, who analysed part of the isotope samples at the UNESCO-IHE laboratory. The research would not have been possible without their kind co-operation in collecting the samples and laboratory analysis.

Edited by: F. Fenicia

\section{References}

Aravena, R., Suzuki, O., Pena, H., Grilli, A., Pollastri, A., and Fuenzalida, H.: Isotopic composition and origin of the precipitation in Northern Chile, Appl. Geochem., 14, 411-422, 1999.

Barthold, F. K., Wu, J., Vache, K. B., Schneider, K., Frede, H. G., and Breuer, L.: Identification of geographic runoff sources in a data sparse region: hydrological processes and the limitations of tracer-based approaches, Hydrol. Process, 24, 23132327, doi:10.1002/hyp.7678, 2010.
Bewket, W. and Sterk, G.: Dynamics land cover and its effect on the streamflow on the Chemoga watershed in the Blue Nile basin, Ethiopia, Hydrol. Processes., 19, 445-458, 2005.

Bliss, C. I.: Periodic Regressions Statistics in Biology, McGrawHill Book Co., New York, USA, 219-287, 1970.

Botter, G., Bertuzzo, E., and Rinaldo, A..: Catchment residence and travel time distributions: The master equation, Geophys. Res. Lett., 38, L11403, doi:10.1029/2011GL047666, 2011.

Buttle, J. M.: Isotope hydrograph separations and rapid delivery of pre-event water from drainage basins, Prog. Phys. Geogr., 18, 16-41, 1994.

Dansgaard, W.: Stable isotopes in precipitation, Tellus, 16, 436468, 1964.

Darling, W. G. and Gizaw, B.: Rainfall-groundwater isotopic relationships in eastern Africa: the Addis Ababa anomaly. Study of environmental change using isotopic techniques, C\&S Papers Series, IAEA, 489-490, 2002.

Didszun, J. and Uhlenbrook, S.: Scaling of dominant runoff generation processes: Nested catchments approach using multiple tracers, Water Resour. Res., 44, W02410, doi:10.1029/2006WR005242, 2008.

Dunn, S. M., McDonnell, J. J., and Vache, K. B.: Factors influencing the residence time of catchment waters: A virtual experiment approach, Water Resour. Res., 43, W06408, doi:10.1029/2006WR005393, 2007.

Gat, J. R., Bowser, C. J., and Kendall, C.: The contribution of evaporation from the Great Lakes to the continental atmosphere: Estimate based on stable isotope data, Geophys. Res. Lett., 21, 557560, 1994.

Gat, J. R.: Oxygen and Hydrogen isotopes in the hydrologic cycle, Annu. Rev. Earth Planet. Sci., 24, 225-262, 1996.

Genereux, D. P.: Quantifying uncertainty in tracer based hydrograph separation, Water Resour. Res., 34, 915-919, 1998.

Gibson, J. J., Edwards, T. W. D., Birks, S. J., Amour, N. A. St., Buhay, W. M., McEachern, P., Wolfe, B. B., and Peters, D. L.: Progress in isotope tracer hydrology in Canada, Hydrol. Process., 19, 303-327, doi:10.1002/hyp.5766, 2005.

Hargreaves, G. H. and Samani, Z. A.: Estimating potential evaporation, J. Irrig. Drain. E.-ASCE, 108, 225-230, 1982.

Heidbüchel, I., Troch, P. A., Lyon, S. W., and Weiler, M.: The master transit time distribution of variable flow systems, Water Resour. Res., 48, W06520, doi:10.1029/2011WR011293, 2012.

Hrachowitz, M., Soulsby C., Tetzlaff, D., Dawson, J. J. C., Dunn, S. M., and Malcolm, I. A.: Using longer-term data sets to understand transit times in contrasting headwater catchments, J. Hydrol., 367, 237-248, doi:10.1016/j.jhydrol.2009.01.001, 2009.

Hrachowitz, M., Bohte, R., Mul, M. L., Bogaard, T. A., Savenije, H. H. G., and Uhlenbrook, S.: On the value of combined event runoff and tracer analysis to improve understanding of catchment functioning in a data-scarce semi-arid area, Hydrol. Earth Syst. Sci., 15, 2007-2024, doi:10.5194/hess-15-2007, 2011a.

Hrachowitz, M., Soulsby, C., Tetzlaff, I., and Malccolm, A.: Sensitivity of mean transit time estimates to model conditioning and data availability, Hydrol. Processes., 25, 980-990, 2011 b.

Hrachowitz, M., Savenije, H., Bogaard, T. A., Tetzlaff, D., and Soulsby, C.: What can flux tracking teach us about water age distribution patterns and their temporal dynamics?, Hydrol. Earth Syst. Sci., 17, 533-564, doi:10.5194/hess-17-533-2013, 2013. 
Hargreaves, G. H. and Samani Z. A.: Estimating potential evaporation, J. Irrig. Drain. Eng., 108, 225-230, 1982.

International Atomic Energy Agency.: IAEA-WMO Programme on Isotopic Composition of Precipitation: Global Network of Isotopes In Precipitation (GNIP) Technical procedure for sampling, 2009.

Joseph, A., Frangi, P., and Aranyossy, J. F.: Isotopic composition of Meteoric water and groundwater in the Sahelo-Sudanese Zone, J. Geophys. Res., 97, 7543-7551, 1992.

Kebede, S.: Approaches isotopique et geochimique pour l'etudedes eaux souterraines et des lacs: Examples du haut bassin du Nil Bleu et du rift Ethiopien [Environmental isotopes and geochemistry in groundwater and lake hydrology: cases from the Blue Nile basin, main Ethiopian rift and Afar, Ethiopia], $\mathrm{PhD}$ thesis, University of Avignon, France, 2004, p. 162, 2004.

Kebede, S. and Travi, Y.: Origin of the $\delta^{18} \mathrm{O}$ and $\delta^{2} \mathrm{H}$ composition of meteoric waters in Ethiopia, Quatern. Int., 257, 4-12, doi:10.1016/j.quaint.2011.09.032, 2012.

Kebede, S., Travi, Y., Alemayehu, T., Ayenew, T., and Aggarwal, P.: Tracing sources of recharge to ground waters in the Ethiopian Rift and bordering plateau: isotopic evidence, Fourth International Conference on Isotope for Groundwater Management, IAEA-CN-104/36, 19-22 May, Vienna, IAEA, 19-20, 2003.

Kendall, C. and Caldwell, E. A.: Fundamentals of isotope geochemistry, in: Isotope Tracers in Catchment Hydrology, edited by: Kendall, C. and McDonnel, J. J., Elsevier Science, Amsterdam, 51-86, 1998.

Kendall, C. and Coplen, T. B.: Distribution of oxygen -18 and deuterium in river waters across the United States, Hydrol. Process., 15, 1363-1393, doi:10.1002/hyp.217, 2001.

Kirchner, J. W., Tetzlaff, D., and Soulsby, C.: Comparing chloride and water isotopes as hydrological tracers in two Scottish catchments, Hydrol. Process., 24, 1631-1645, doi:10.1002/hyp.7676, 2010.

Laudon, H., Sjöblom, V., Buffam, I., Seibert, J., and Mörth, M.: The role of catchment scale and landscape characteristics for runoff generation of boreal stream, J. Hydrol., 344, 198-209, doi:10.1016/j.jhydrol, 2007.

Levin, N. E., Zipser, E. J., and Cerling, T. E.: Isotopic composition of waters from Ethiopia and Kenya: Insight into moisture sources for eastern Africa, J. Geophys. Res., 114, D23306, doi:10.1029/2009JD012166, 2009.

Liu, Y., Fan, N., An, S., Bai, X., Liu, F., Xu, Z., Wang, Z., and Liu, S.: Characteristics of water isotopes and hydrograph separation during the wet season in the Heishui River, China, J. Hydrol., 353, 314-321, 2008.

Maloszewski, P. and Zuber, A.: Determining the turnover time of groundwater systems with the aid of environmental tracers, Models and their applicability, J. Hydrol., 57, 207-231, 1982.

McDonnell, J. J.: A rational for old water discharge through macro pores in a steep humid catchment, Water Resour. Res., 26, 28212832, 1990.

McDonnell, J. J., Bonell, M., Stewart, M. K., and Pearce, A. J.: Deuterium variations in storm rainfall-Implications for stream hydrograph separation, Water Resour. Res., 26, 455-458, 1990.

McDonnell, J. J., Stewart, M. K., and Owens, I. F.: Effect of catchment scale subsurface mixing on stream isotopic response, Water Resour. Res., 27, 3065-3073, 1991.
McGlynn, B., McDonnell, J., Stewart, M., and Seibert, J.: On the relationship between catchment scale and stream water mean residence time, Hydrol. Process., 17, 175-181, 2003.

McGuire, K. J., DeWalle, D. R., and Gburek, W. J.: Evaluation of mean residence time in subsurface waters using oxygen-18 fluctuations during drought conditions in the semi-Appalachains, J. Hydrol., 261, 132-149, 2002.

McGuire, K. J., McDonnell, J. J., Weiler, M., Kendall, C., McGlynn, C. L., Welker, J. L., and Siebert, J.: The role of topography on catchment scale water residence time, Water Resour. Res., 41, W05002, doi:10.1029/2004WR003657, 2005.

McGuire, K. J. and McDonnell, J. J.: A review and evaluation of catchment transit time modeling, J. Hydrol., 330, 543-563, 2006.

Mohamed, Y. A., van den Hurk, B. J. J. M., Savenije, H. H. G., and Bastiaanssen, W. G. M.: Hydroclimatology of the Nile: results from a regional climate model, Hydrol. Earth Syst. Sci., 9, 263278, doi:10.5194/hess-9-263-2005, 2005.

Mul, M. L., Mutiibwa, K. R., Uhlenbrook, S., and Savenije, H. H. G.: Hydrograph separation using hydrochemical tracers in the Makanya catchment, Tanzania, Phys. Chem. Earth., 33, 151-156, 2008.

Munyaneza, O., Wenninger, J., and Uhlenbrook, S.: Identification of runoff generation processes using hydrometric and tracer methods in a meso-scale catchment in Rwanda, Hydrol. Earth Syst. Sci., 16, 1991-2004, doi:10.5194/hess-16-1991, 2012.

NMSA (National Meteorological service Agency): Climatic and agroclimatic resources of Ethiopia, NMSA Meteorological Research Report Series, Vol. 1, No. 1, Addis Ababa, p. 137, 1996.

Pearce, A. J., Stewart, M. K., and Sklash, M. G.: Storm runoff generation in humid headwater catchments. Where does the water come from?, Water Resour. Res., 22, 1263-1272, 1986.

Rodgers, P., Soulsby, C., Waldron, S., and Tetzlaff, D.: Using stable isotope tracers to assess hydrological flow paths, residence times and landscape influences in a nested mesoscale catchment, Hydrol. Earth Syst. Sci., 9, 139-155, doi:10.5194/hess-9-139-2005, 2005a.

Rodgers, P., Soulsby, C., and Waldron, S.: Stable isotope tracers as diagnostic tools in up scaling flow path understanding and residence time estimates in a mountainous mesoscale catchment, Hydrol. Process. 19, 2291-2307, 2005b.

Rozanski, K., Araguás-Araguás, L., and Gonfiantini, R.: Isotopic patterns in modern global precipitation, in climate change in Continetal Isotopic Records, Geophysical Monograph 78, American Geophysical Union, 1-36, 1993.

Rozanski, K., Araguás-Araguás, L., and Gonfiantini, R.: Isotope patterns of precipitation in the east African region, in: The Liminology, Climatology and Paleoclimatology of the East African Lakes, edited by: Johnson, T. C. and Odada, E., Gordon and Breach, Toronto, 79-93, 1996.

Shanley, J. B., Kendall, C., Smith, T. E., Wolock, D. M., and McDonnell, J. J.: Controls on old and new water contributions to stream flow at some nested catchments in Vermont, USA, Hydrol. Processes., 16, 589-609, 2002.

Sklash, M. G. and Farvolden, R. N.: The role of groundwater in storm runoff, J. Hydrol., 43, 45-65, doi:10.1016/00221694(79)90164-1, 1979.

Soulsby, S. and Tetzlaff, D.: Towards simple approaches for mean residence time estimation in ungauged basins using tracers and soil distributions, J., Hydrol., 363, 60-74, 2008. 
Soulsby, C., Malcolm, R., Helliwell, R., Ferrier, R. C., and Jenkins, A.: Isotope hydrology of the Allt a' Mharcaidh catchment, Cairngorms, Scotland: implications for hydrological pathways and residence times, Hydrol. Processes., 14, 747-762, 2000.

Soulsby, C., Tetzlaff, D., Dunn, S. M., and Waldron, S.: Scaling up and out in runoff process understanding: insight from nested experimental catchment studies, Hydrol. Processes., 20, 2461$2465,2006$.

Taylor, C. B., Wilson, D. D., Borwn, L. J., Stewart, M. K., Burdon, R. J., and Brailsford, G. W.: Sources and flow of North Canterbury plains ground water, New Zealand, J. Hydrol., 106, 311340, 1989.

Teferi, E., Uhlenbrook, S., Bewket, W., Wenninger, J., and Simane, B.: The use of remote sensing to quantify wetland loss in the Choke Mountain range, Upper Blue Nile basin, Ethiopia, Hydrol. Earth Syst. Sci., 14, 2415-2428, doi:10.5194/hess-14-24152010, 2010.

Teferi, E., Bewket, W., Uhlenbrook, S., and Wenninger, J.: Understanding recent land use and land cover dynamics in the source region of the Upper Blue Nile, Ethiopia: Spatially explicit statistical modeling of systematic transitions, Agr. Ecosyst. Environ., 165, 98-117, 2013.

Tekleab, S., Uhlenbrook, S., Mohamed, Y., Savenije, H. H. G., Temesgen, M., and Wenninger, J.: Water balance modeling of Upper Blue Nile catchments using a top-down approach, Hydrol. Earth Syst. Sci., 15, 2179-2193, doi:10.5194/hess-15-21792011, 2011.

Tekleab, S., Mohamed, Y., Uhlenbrook, S., and Wenninger, J.: Hydrologic responses to land cover change, the case of Jedeb mesoscale catchment, Abay/Upper Blue Nile basin, Ethiopia, Hydrol. Process., doi:10.1002/hyp.9998, in press, 2013.

Temesgen, M., Uhlenbrook, S., Simane, B., van der Zaag, P., Mohamed, Y., Wenninger, J., and Savenije, H. H. G.: Impacts of conservation tillage on the hydrological and agronomic performance of Fanya juus in the upper Blue Nile (Abbay) river basin, Hydrol. Earth Syst. Sci., 16, 4725-4735, doi:10.5194/hess-164725-2012, 2012.
Tetzlaff, D., Waldron, S., Brewer, M. J., and Soulsby, C.: Assessing nested hydrological and hydochemical behaviour of a mesoscale catchment using continuous tracer data, J. Hydrol., 336, 430 443, 2007a.

Tetzlaff, D., Soulsby, C., Waldron, S., Malcolm, I. A., Bacon, P. J., Dunn, S. M., and Lilly, A.: Conceptualization of runoff processes using GIS and tracers in a nested mesoscale catchment, Hydrol. Processes., 21, 1289-1307, 2007b.

Tetzlaff, D., Seibert, J., and Soulsby, C.: Inter-catchment comparison to assess the influence of topography and soils on catchment transit times in a geomorphic province; in a Cairngorm Mountains Scotland, Hydrol. Processes., 23, 1874-1886, 2009.

Uhlenbrook, S. and Hoeg, S.: Quantifying uncertainties in tracer based hydrograph separations: a case study for two, three and five component hydrograph separations in a mountainous catchment, Hydrol. Processes., 17, 431-453, 2003.

Uhlenbrook, S. and Leibundgut, C.: Process-oriented catchment modeling and multiple-response validation, Hydrol. Processes., 16, 423-440, doi:10.1002/hyp.330, 2002.

Uhlenbrook, S., Frey, M., Leibundgut, C., and Maloszewski, P.: Hydrograph separations in a mesoscale mountainous basin at event and seasonal time scales, Water Resour. Res., 38, 1-13, 2002.

Van der Velde Y., de Rooij, G. H., Rozemeijer, J. C., Van Geer, F. C., and Broers, H. P.: Nitrate response of a lowland catchment: On the relation between stream concentration and travel time distribution dynamics,. Water Resour. Res., 46, W11534, doi:10.1029/2010WR009105, 2010.

Viste, E. and Sorteberg, A.: Moisture transport into the Ethiopia highlands, Int. J. Climatol., 33, 249-263, 2013.

Wels, C., Cornett, R. J., and Lazerte, B. D.: Hydrograph separation: a comparison of geochemical and isotopic tracers, J. Hydrol., 122, 253-274, 1991.

Wissmeier, L. and Uhlenbrook, S.: Distributed, high-resolution modeling of ${ }^{18} \mathrm{O}$ Signals in a meso-scale catchment, J. Hydrol., 332, 497-510, doi:10.1016/j.jhydrol.2006.08.003, 2007. 